\title{
A GEOTOURISTIC ITINERARY: A PROPOSAL FOR GEOTOURISM AND ARCHAEOTOURISM DEVELOPMENT OF LENGGONG VALLEY, PERAK, MALAYSIA
}

\author{
Mat Stafa RAPIDAH* \\ School of Environmental and Natural Resources Sciences, Faculty of Science and Technology, \\ University Kebangsaan Malaysia, 4360o UKM Bangi, Malaysia, e-mail: rapidahms@gmail.com
}

\section{Kamal Roslan MOHAMED}

School of Environmental and Natural Resources Sciences, Faculty of Science and Technology, University Kebangsaan Malaysia, 43600 UKM Bangi, Malaysia, e-mail: kamal@ukm.edu.my

\section{Che Aziz ALI}

School of Environmental and Natural Resources Sciences, Faculty of Science and Technology, University Kebangsaan Malaysia, 43600 UKM Bangi, Malaysia, e-mail: che@ukm.edu.my

\section{Mohd Shafeea LEMAN}

School of Environmental and Natural Resources Sciences, Faculty of Science and Technology, University Kebangsaan Malaysia, 43600 UKM Bangi, Malaysia, e-mail: shafeea@ukm.edu.my

\section{Mokhtar SAIDIN}

Centre for Global Archaeological Research, University Sains Malaysia, 11800 Pulau Pinang, Malaysia, e-mail: mmokh@usm.my

\begin{abstract}
Citation: Rapidah, M.S., Mohamed, K.R., Ali, C.A., Leman, M.S., \& Saidin M. (2018). A GEOTOURISTIC ITINERARY: A PROPOSAL FOR GEOTOURISM AND ARCHAEOTOURISM DEVELOPMENT OF LENGGONG VALLEY, PERAK, MALAYSIA. GeoJournal of Tourism and Geosites, 22(2), 597-624. https://doi.org/10.30892/gtg.22227-314
\end{abstract}

\begin{abstract}
The Archaeological Heritage of Lenggong Valley has a high potential to be developed as geotourism and archaeotourism destination. The diversity in geology and geomorphology of the area represent scientific, cultural, aesthetic as well as recreational values and together define the geodiversity of this area. This paper proposes a basic geotouristic itinerary connects a series of impressive geosites distributed in Lenggong Valley which can explain the high potential interest of the area in geotourism and archaeotourism terms. In order to enhance and highlight their importance to the geological and archaeological heritage, the location, accessibility, important geological-scientific features or historical-cultural interest, related activities as well as available facilities was described. The motivation for establishing this itinerary mostly resides in the great scientific and cultural interest of the geosites that will hopefully facilitate their conservation and the development of geo-archaeotourism to continuously attract a large number of visitors year by year. The itinerary can be used for teaching purposes at different educational levels, geotourists and geopark guides and for university courses. In addition, non-geologists may follow the itinerary guided by expert volunteers to discover the geological and archaeological heritage of the area.
\end{abstract}

\footnotetext{
* Corresponding author
} 
Mat Stafa RAPIDAH, Kamal Roslan MOHAMED,

Che Aziz ALI, Mohd Shafeea LEMAN, Mokhtar SAIDIN

Key words: geotourism, archaeotourism, geotouristic itinerary, geo-archaeotourism development, Archaeological Heritage of Lenggong Valley

\section{INTRODUCTION}

A geosite is understood as a remarkable geological location where one or more elements of geodiversity are present and unique values of scientific, pedagogical, cultural or touristic interest are shown. According to Komoo (2004), geosite refers to any geological site or landform which contains a significant geodiversity component that indicates the high geoheritage value. Geosites present a particular importance for the comprehension of Earth history, geological or geomorphological objects and evidence of ancient life (Migon \& Pijet-Migon, 2016) that have acquired scientific and additional values as due to human perception or exploitation (Kubalíková, 2013) as well as to its potential of use (Fassoulas et al., 2012). According to Newsome \& Dowling (2010), geotourisn is form of natural area tourism that specifically focuses on landscape and geology. It promotes tourism to geosite and the conservation of geodiversity and an understanding of earth sciences through appreciation and learning. This is achieved through independent visits to geological features, use of geo-trails and viewpoints, guided tours, geo-activities and patronage of geosite visitor centres. Geotourism has developed to address the need to minimize the negative impacts of mass tourism at tourist sites based around geological and geomorphological attractions. They stress that its central goal is an emphasis on sustainable tourism development in primarily rural and natural environments (Ólafsdóttir \& Dowling, 2014). Geotourism can also be understood at a broader sense as geographical tourism or tourism that sustains or enhances the geographical character of a place - its environment, culture, aesthetics, heritage, and the well-being of its residents (Kubalíková, 2013). This concept is similar to the geomorphosite concept - it does not include only the abiotic features, but it takes into account cultural and aesthetic values (Panizza \& Piacente, 2008; Reynard, 2008).

The Lenggong Valley (Figure 1) is in an area extending from $5^{\circ} 4^{\prime} 40^{\prime \prime} \mathrm{N}$ to $5^{\circ} 8^{\prime} 57^{\prime \prime} \mathrm{N}$ and $100^{\circ} 58^{\prime} 20^{\prime \prime}$ E to $100^{\circ} 59^{\prime} 31^{\prime \prime}$ E. Lenggong Valley is a sub district in Hulu Perak, located in the State of Perak, upper Peninsular Malaysia and bordered by the states of Kelantan, Pahang, Selangor, Penang and Kedah. It is thus located about $100 \mathrm{~km}$ from the state capital, Ipoh. The area is easily accessible by land from neighbouring state by the excellent Malaysia's prime North-South Highway and several alternative trunk roads. It was declared as a World Heritage Site in 2012 for its outstanding cultural value. Lenggong Valley is the fourth World Heritage Site for Malaysia and the 935rd in the world. It possesses beautiful geological landforms, unique geological phenomena and precious earth materials including hills, caves, waterfalls, river and quaternary deposits. Lenggong Valley is commonly considered by tourists and students alike for its renowned archaeological site. It offers an abundance of archaeological and geological evidences that pinned this area in the world's scientific and archaeological map. It has an exceptional archaeological site containing evidence of human habitation traversing through three prehistoric periods, known as Palaeolithic, Neolithic and Metal, holds the key to one of the longest hominid histories dated from 1.83 million to 1,00o years ago in a single locality together with relatively undisturbed in-situ stone tool workshops and existence of early hominid presence outside Africa with the discovering of a unique Palaeolithic skeleton - Perak Man in Gua Gunung Runtuh (Department of National Heritage, 2011). The extraordinary existence of Palaeolithic stone tools found in Bukit Bunuh area was protected by melted suevite from 
A Geotouristic Itinerary of Geosites: A Proposal for Geotourism and Archaeotourism Development of Lenggong Valley, Perak, Malaysia

meteorite strikes about 1.83 million years ago. This has contributed to undisturbed in-situ sites has made Lenggong Valley an obvious prehistoric site for inscription as World Heritage Site by United Nations Educational, Scientific and Cultural Organization (UNESCO) in 2012 and known as the Archaeological Heritage of Lenggong Valley (AHLV).

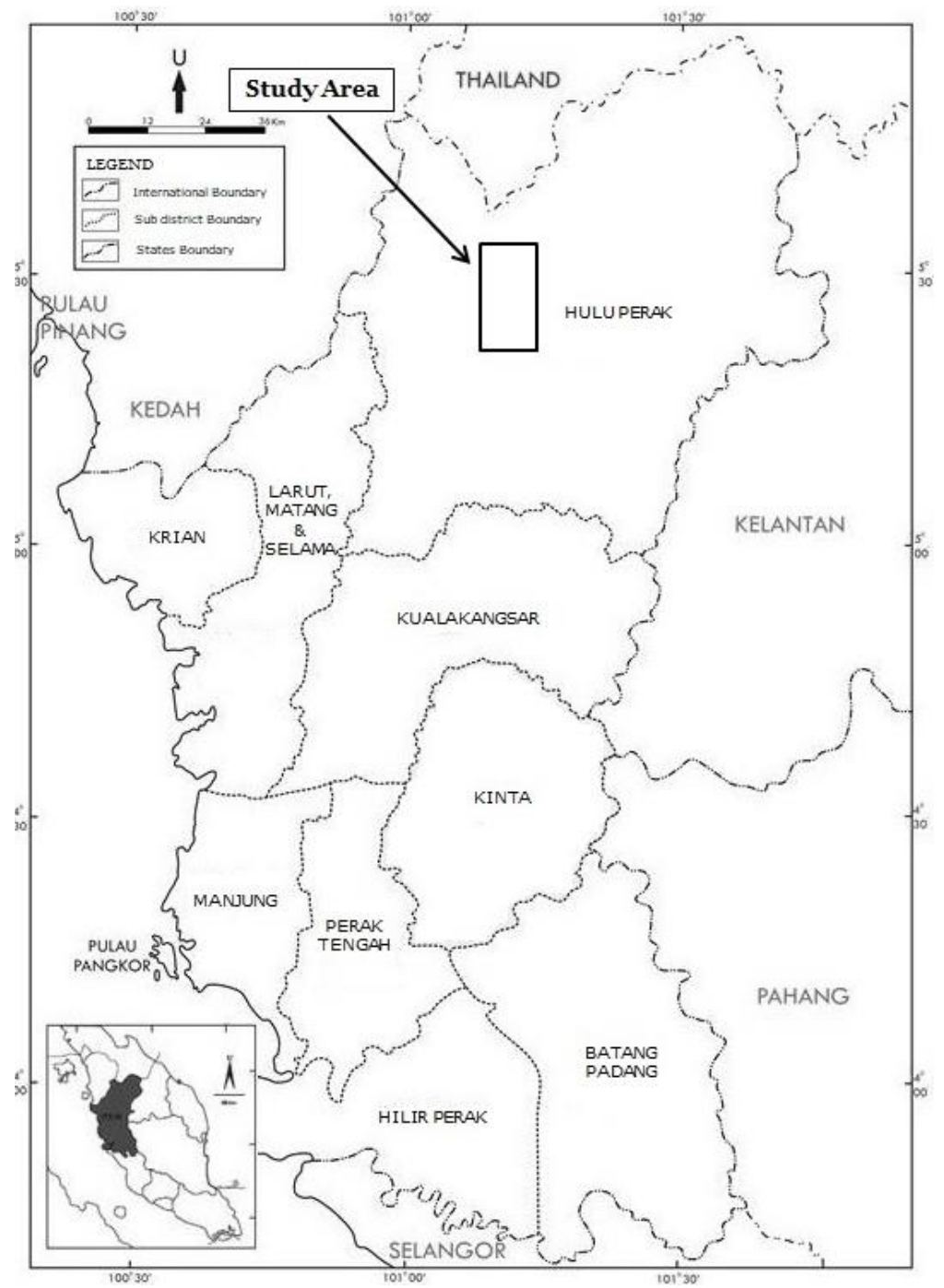

Figure 1. Location map of the study area.

Lenggong Valley is located in the upper art of erak state, Malaysia

The place is like an open-air museum and is home to legends, skeletons, cave drawings and previous finds such as jewellery, pottery, weapons and stone tools. The Lenggong Valley covers an area of 9,773 hectares and the size of the nominated property for the World Heritage Site is 2,185.41 hectares (Department of National Heritage, 2011). For the management purposes, this area has been divided into three zone categories which include the "core zone", "buffer zone" and "buffer to buffer zone". Most of the geosites located in the core zone (except Bukit Sapi area, Lata Kekabu and Sungai Perak) 
that were divided into two clusters (Cluster 1 and 2), located $5 \mathrm{~km}$ apart on the Sungai Perak separated by Lenggong Town (Figure 2). Cluster 1 consists of the Bukit Bunuh-Kota Tampan core zone and its own buffer zone, while Cluster 2 consists of three core zones, namely Bukit Kepala Gajah, Bukit Gua Harimau and Bukit Jawa, all enclosed within a single buffer zone. All the area outside of Cluster 1 and Cluster 2 is known as "buffer to buffer zone". The share lithic tradition in the two clusters serves as the common element to hold the two clusters together as a single nominated property. The area located between the boundary of the core zones' buffers and the boundary of the Special Area Plan (SAP) is known as buffer to buffer zone (Department of National Heritage, 2011).

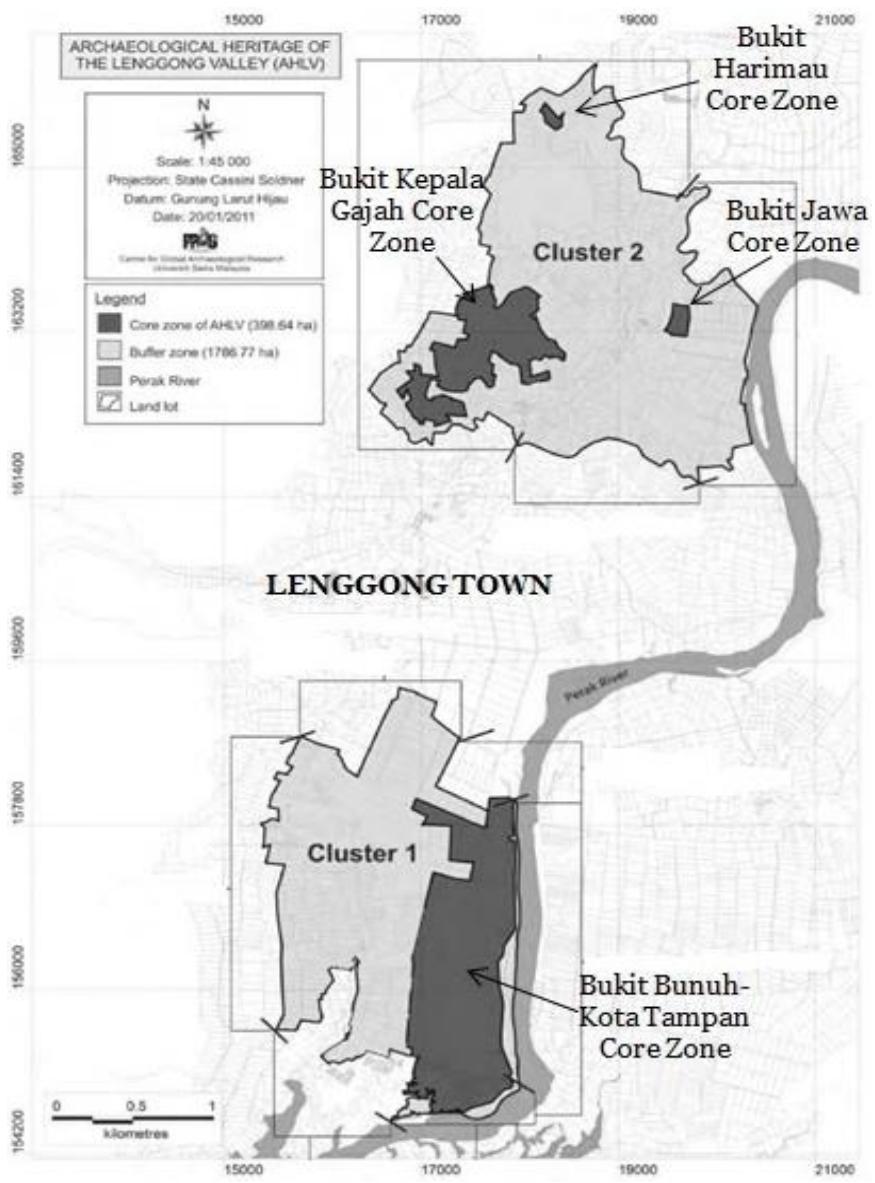

Figure 2. Core zone divided into two clusters - Clusters 1 and Cluster 2 separated by Lenggong Town (Source: Department of National Heritage, 2011)

The main aim of this paper is to present an itinerary to promote all geosites in Lenggong Valley in a scientifically correct way but accessible to the visitors ranging from non-specialist to academic geologists, the most significant steps for geotourism and archaeotourism development. It was designed to illustrate and enhance the natural history of this area from geological and archaeological perspectives as well as demonstrate how humans interacted with that environment in pre-historic times. The itinerary combines the main geosites, namely Bukit Bunuh, Kota Tampan, Bukit Jawa, Bukit Sapi, 
Batu Berdinding, Lata Kekabu, Sungai Perak and Bukit Kepala Gajah Complex that contains several caves such as Gua Gunung Runtuh, Gua Teluk Kelawar, Gua Harimau, Gua Kajang- Asar-Puteri, with nearby supporting tourism product such as Tasik Raban Restaurant, Homestay Kampung Beng, Kota Tampan Archaeological Museum and Archaeological Research Centre (PLA USM). Each of the chosen geosite contains multidisciplinary geological and archaeological information. Thus, each of these sites containing particular geological features represents an important part of the cultural component because they are connected to historical events. They are also have been selected by taking into account some fundamental features such as good quality of the exposure, aesthetic and recreational values as they are surrounded by a pristine landscape with an interesting fauna and flora, which can be observed during the trip.

\section{GEOLOGICAL SETTING}

Geologically, the dynamic landscape of Lenggong Valley is flanked by two majestic granite mountain ranges known as Main Ridge Granite on the east and Bintang Granite on the west with the highest point at $1077 \mathrm{~m}$ and slow meandering Sungai Perak as its spine that brings life to the valley, which flows N-S through this valley (Figure 3). Bintang Granite intrusion during Triassic time contains coarse-grained porphyritic adamellite-granite and medium-grained granite with biotite as the mafic mineral (Mohamed et al., 2012). These two granite bodies are huge batholith that caused the uplifted and the whole Peninsular Malaysia became a continent (Rushdan, 1994). The S-type of Bintang Granite turns the limestone, arenacoeus and argillaceous rock of Kroh Formation into marble, quartzite and phyllite respectively (Mohamed et al., 2012). The archaeological study in AHLV has revealed a hidden throne of rich geological heritage of the area.

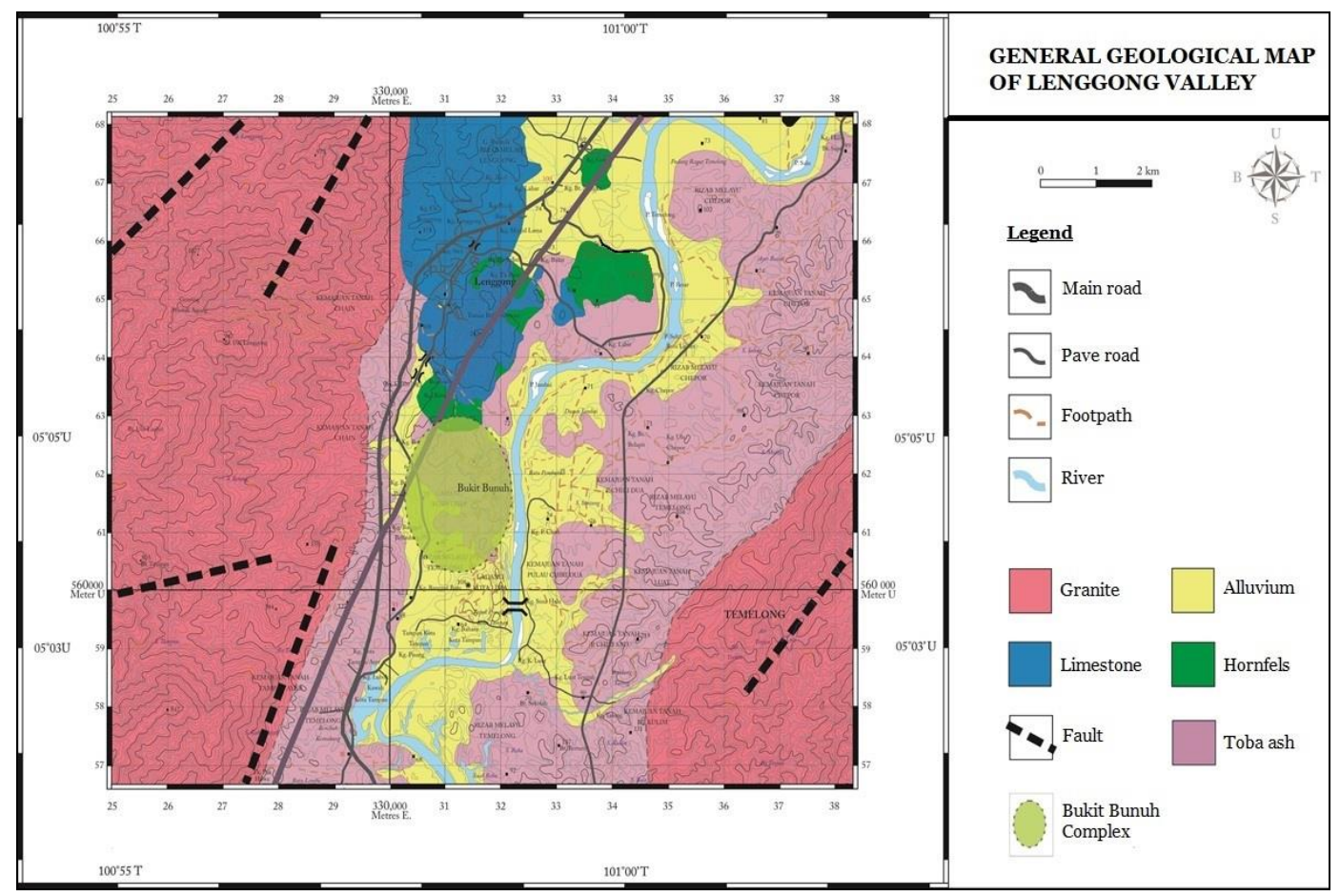

Figure 3. General geological map of Lenggong Valley (modified after Nur Asikin, 2013) 
Despite its small size, this valley was bounded by two main granite bodies, has beautiful landscape and other geological elements such as caves, waterfall and v-shaped river valley that bear high geotourism and archaeotourism potential. The area has a wide spectrum of rock types and palaeoenvironments. It has granite intrusion together with shallow marine clastic as well as remaining quaternary deposits such old alluvial deposits and volcanic ash, largely deposited along the Sungai Perak. Volcanic ash known as Toba Ash has been dated approximately 74,000 years old. The most prominent geological heritage of the area is a new rock complex as the results of meteorite impact occurred at 1.83 million years ago (Department of National Heritage, 2011; Saidin, 2012a, 2012b; Mohamed et al., 2012). Areas of Bukit Bunuh consist of blocks of suevite rocks, partially to completely molten rocks, polymict impact breccias and impact granite and metasedimentary rocks.

Data from drilling also show that the granite in Bukit Bunuh was impacted, and this suggests that meteorite impact occurred at Bukit Bunuh. All the blocks and also the granite which have been formed or deformed by the impact of this meteorite have been suggested to form a new stratigraphic unit (Mohamed et al., 2012) known as Bukit Bunuh Complex (Figure 3). The clastic sediments were metamorphosed and form a complex of limestone properties with several caves. Weathering and erosion of limestone have produced karst morphology and with beautiful cave formations. All the caves are very special in the sense of prehistoric habitat. Many caves within these properties are being excavated by archaeologist to obtain information on Palaeolithic civilization. The Perak Man skeleton remained almost intact for more than 10,000 years was excavated in Gua Gunung Runtuh in the property of Bukit Kepala Gajah (Department of National Heritage, 2011). AHLV offers outstanding scientific, aesthetic, cultural and recreational values that make the area very important in terms of geoheritage conservation. The geological features which provide useful insight into the geological history of the area may be utilized for educational purpose, as in geological tourism to add value to the existing attraction and archaeological heritage of the site. AHLV as a prominent archaeological site and rich with geodiversity could be promoted as geotourism and archaeotourism destination. The sprint off geotourism and archaeotourism development could benefit the locals and that would encourage them to conserve the geological and archaeological heritage resources of the area.

\section{METHODOLOGY}

Scientific interest, accessibility and good exposure of outcrops associated with historical-cultural resources as well as recreational and aesthetic values were essential components (Bentivenga et al., 2017; Palladino et al., 2013) for the development of the geotouristic itinerary in the AHLV. In this paper, we will first outline the location and accessibility of the geosite followed by geological-scientific features or historical-cultural interest in order to highlight their importance to the geological and archaeological heritage of the Lenggong Valley. Then, we will describe the stops on the geotouristic itinerary based on diversity, geological formation, uniqueness and current conservation status with all the information from the previous literature and the field observation. The geotouristic itinerary is designed to present, illustrate and enhance the natural history of this area from a geological perspective as well as demonstrate how humans have interacted with that environment in prehistoric times. The main reason for choosing Lenggong Valley for the itinerary is the scientific and cultural interests of the area and the presence of important geosites. However, this choice also derives from the recognition of this area as the World Heritage Site and enthusiasm of the local authorities, who provide maintenance for the sites. Currently, the key geosites within the area are protected and managed by the local administration (Department of National Heritage) and the research and development 
including scientific and educational studies within the site is taking care by the Centre for Global Archaeological Research (CGAR) from University Sains Malaysia (USM). We believe, however, that the geological itinerary may play a fundamental role in the geoconservation of this special area, by raising the awareness of geological heritage within the local population.

\section{GEOTOURISTIC ITINERARY}

Geosites of AHLV were divided into two main groups based on their accessibility; (i) easy to access and (ii) difficult to access. Consequently, two-full day is needed to visit all the geosites. Easy access geosites are located nearby the main state and/or municipal roads that are used in the itinerary. Roads are generally in good conditions and can be travelled by car and/or motorbike. A short walk may be necessary for reaching the geosites and the best viewpoints. Bukit Bunuh, Kota Tampan, Bukit Jawa, Bukit Sapi, Batu Berdinding, Gua Kajang - Puteri - Asar, Sungai Perak and Lata Kekabu were considered as easy access geosites (Figure 4, see Table 1).

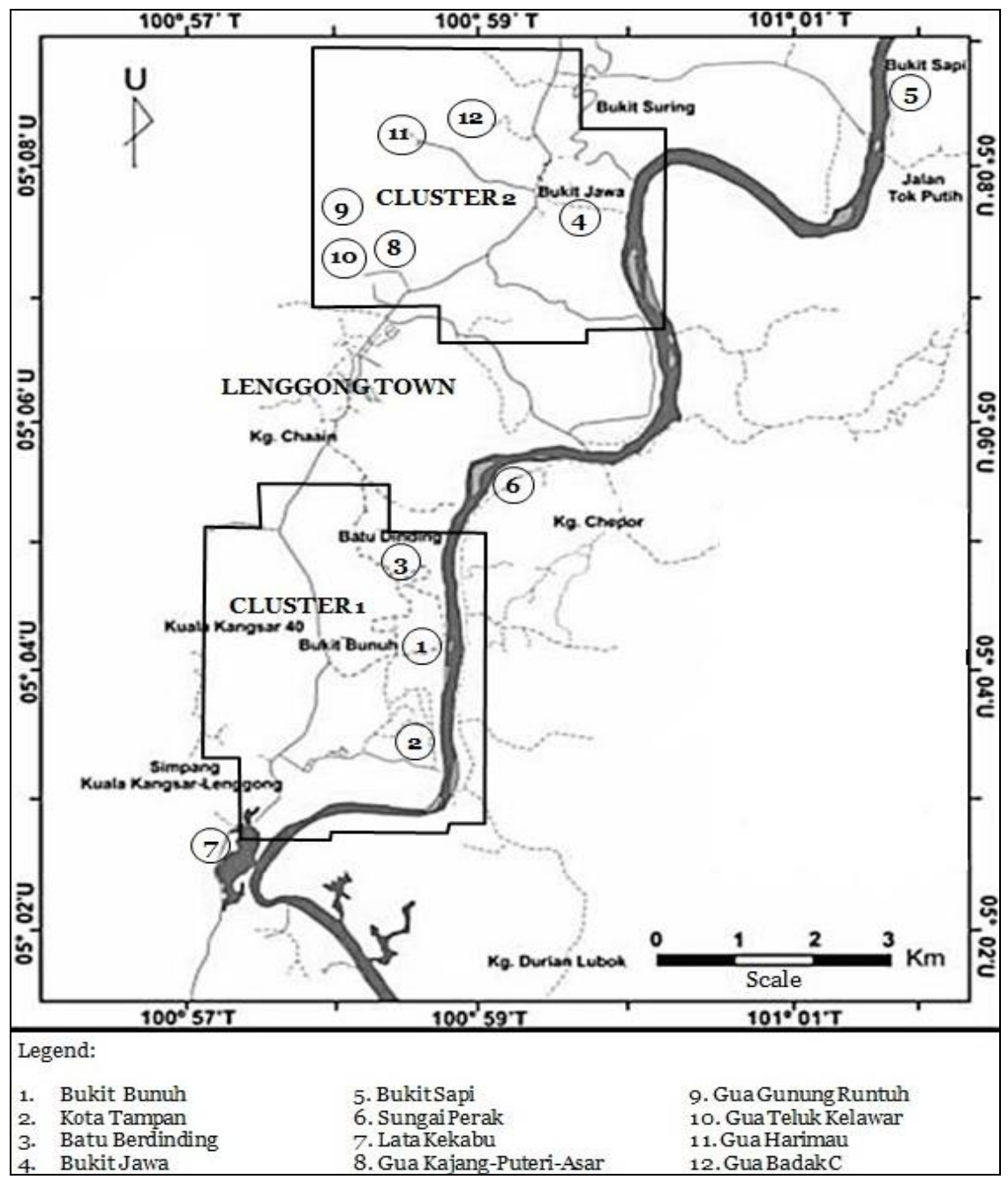

Figure 4. The selected geosites in AHLV for this study (Source: Dossier of Archeological Heritage of Lenggong Valley, Department of National Heritage, 2011) 
Table 1: List of geosite in Lenggong Valley, coordinates, altitude,

distance from Lenggong Town, accessibility and their related activities on site

\begin{tabular}{|c|c|c|c|c|c|c|}
\hline No. & $\begin{array}{l}\text { Name of } \\
\text { Geosite }\end{array}$ & $\begin{array}{l}\text { Latitude/ } \\
\text { Longitude }\end{array}$ & $\begin{array}{l}\text { Altitude } \\
\text { (m.a.s.l) }\end{array}$ & \begin{tabular}{|c|} 
Distance from \\
Lenggong \\
Town
\end{tabular} & Accessibility & Related activities \\
\hline 1 & $\begin{array}{l}\text { Bukit } \\
\text { Bunuh }\end{array}$ & $\begin{array}{l}5^{\circ} \mathrm{O} 4^{\prime} 30^{\prime \prime} \mathrm{N} / \\
100^{\circ} 58^{\prime} 34^{\prime \prime} \mathrm{E}\end{array}$ & 180 & $10 \mathrm{~km}$ & $\begin{array}{l}\text { Motorbike and } \\
\text { four wheel drives }\end{array}$ & $\begin{array}{l}\text { Visiting for research and } \\
\text { educational purposes }\end{array}$ \\
\hline 2 & $\begin{array}{l}\text { Kota } \\
\text { Tampan }\end{array}$ & $\begin{array}{l}5^{\circ} \mathrm{O} 3^{\prime} 18^{\prime \prime} \mathrm{N} / \\
100^{\circ} 58^{\prime} 25 ” \mathrm{E}\end{array}$ & $\begin{array}{l}72- \\
101\end{array}$ & $12 \mathrm{~km}$ & $\begin{array}{l}\text { All means of } \\
\text { transportation }\end{array}$ & $\begin{array}{c}\text { Visiting and } \\
\text { demostration }\end{array}$ \\
\hline 3 & $\begin{array}{l}\text { Batu } \\
\text { Berdinding }\end{array}$ & $\begin{array}{c}5^{\circ} 5^{\circ} 48^{\prime \prime} \mathrm{N} / \\
100^{\circ} 57^{\prime} 53^{\prime \prime} \mathrm{E}\end{array}$ & 108 & $4 \mathrm{~km}$ & $\begin{array}{l}\text { Motorbike and } \\
\text { four wheel drives }\end{array}$ & $\begin{array}{l}\text { Visiting for research and } \\
\text { educational purposes }\end{array}$ \\
\hline 4 & $\begin{array}{l}\text { Bukit } \\
\text { Jawa }\end{array}$ & \begin{tabular}{|l}
$5^{\circ} 07^{\prime} 44^{\prime} \mathrm{N} /$ \\
$100^{\circ} 59^{\prime} 34^{\prime \prime} \mathrm{E}$
\end{tabular} & 104 & $8 \mathrm{~km}$ & $\begin{array}{l}\text { All means of } \\
\text { transportation }\end{array}$ & $\begin{array}{l}\text { Visiting, demostation, } \\
\text { fun excavation, camping }\end{array}$ \\
\hline 5 & $\begin{array}{l}\text { Bukit } \\
\text { Sapi }\end{array}$ & $\begin{array}{l}5^{\circ} 08^{\prime} 48^{\prime \prime} \mathrm{N} / \\
100^{\circ} 01^{\prime} 28^{\prime \prime} \mathrm{E}\end{array}$ & 73 & $18-20 \mathrm{~km}$ & $\begin{array}{l}\text { All means of } \\
\text { transportation }\end{array}$ & $\begin{array}{c}\text { Visiting for research and } \\
\text { educational purposes }\end{array}$ \\
\hline 6 & $\begin{array}{l}\text { Sungai } \\
\text { Perak }\end{array}$ & $\begin{array}{l}5^{\circ} 20^{\prime} 25^{\prime \prime} \mathrm{N}- \\
5^{\circ} \mathrm{OO} \mathrm{O}^{\prime \prime} \mathrm{N} / \\
101^{\circ} 10^{\prime} \mathrm{O} / \mathrm{E}- \\
100^{\circ} \mathrm{O} 9^{\prime} \mathrm{O}=\mathrm{E} \\
\end{array}$ & $<70$ & $\begin{array}{c}\text { not } \\
\text { specific }\end{array}$ & $\begin{array}{l}\text { All means of } \\
\text { transportation } \\
\text { including water } \\
\text { transportion }\end{array}$ & $\begin{array}{l}\text { Water activities including } \\
\text { boating, caneoing and } \\
\text { kayaking }\end{array}$ \\
\hline 7 & $\begin{array}{l}\text { Lata } \\
\text { Kekabu }\end{array}$ & $\begin{array}{l}5^{\circ} \mathrm{O} 2^{\prime} 41^{\prime \prime} \mathrm{N} / \\
100^{\circ} 56^{\prime} 57^{\prime \prime} \mathrm{E}\end{array}$ & $\begin{array}{c}106- \\
130\end{array}$ & $9 \mathrm{~km}$ & $\begin{array}{l}\text { All means of } \\
\text { transportation }\end{array}$ & $\begin{array}{c}\text { Variety of leisure activities } \\
\text { including visiting, camping, } \\
\text { guided hiking, f ishing, } \\
\text { swimming }\end{array}$ \\
\hline \multirow[t]{3}{*}{8} & $\begin{array}{l}\text { Gua } \\
\text { Kajang }\end{array}$ & $\begin{array}{c}5^{\circ} \mathrm{O} 77^{\prime} 71^{\prime \prime} \mathrm{N} / \\
100^{\circ} 58^{\prime} \mathrm{O} 8^{\prime \prime} \mathrm{E}\end{array}$ & 76 & $6 \mathrm{~km}$ & $\begin{array}{l}\text { Motorbike and } \\
\text { four wheel drives } \\
\text { (cave mouth) }\end{array}$ & \multirow{3}{*}{$\begin{array}{l}\text { Main activities } \\
\text { including visiting for } \\
\text { research and educational } \\
\text { purposes, cave exploration } \\
\text { and trekking. }\end{array}$} \\
\hline & $\begin{array}{l}\text { Gua } \\
\text { Asar }\end{array}$ & $\begin{array}{l}5^{\circ} \mathrm{O} 756^{\prime \prime} \mathrm{N} / \\
100^{\circ} 58^{\prime} 80^{\prime \prime} \mathrm{E}\end{array}$ & 78 & $6 \mathrm{~km}$ & $\begin{array}{l}\text { Motorbike, walking } \\
\text { for } 30 \text { minutes } \\
\text { from Gua Kajang }\end{array}$ & \\
\hline & $\begin{array}{l}\text { Gua } \\
\text { Puteri }\end{array}$ & $\begin{array}{l}5^{\circ} 07^{\prime} 53^{\prime \prime N} / \\
100^{\circ} 58^{\prime} 82^{\prime \prime} \mathrm{E}\end{array}$ & 94 & $6 \mathrm{~km}$ & \begin{tabular}{|c|} 
Motorbike, walking \\
for 40 minutes from \\
Gua Kajang, climbing \\
for 15 minutes \\
\end{tabular} & \\
\hline 9 & $\begin{array}{l}\text { Gua } \\
\text { Gunung } \\
\text { Runtuh }\end{array}$ & $\begin{array}{l}5^{\circ} \mathrm{O} 7^{\prime} 3 ” \mathrm{~N} / \\
100^{\circ} 58^{\prime} 3^{\prime \prime} \mathrm{E}\end{array}$ & 124 & $8 \mathrm{~km}$ & \begin{tabular}{|l|} 
Four wheel drives, \\
walking for 30 \\
minutes, climbing \\
for 15 minutes \\
\end{tabular} & $\begin{array}{c}\text { Strictly limited to visiting } \\
\text { outside hills and } \\
\text { excavation areas only }\end{array}$ \\
\hline 10 & $\begin{array}{l}\text { Gua } \\
\text { Teluk } \\
\text { Kelawar }\end{array}$ & $\begin{array}{l}5^{\circ} 07^{\prime} 44^{\prime \prime N} / \\
100^{\circ} 58^{\prime} 6 " \mathrm{E}\end{array}$ & 76 & $7 \mathrm{~km}$ & \begin{tabular}{|l|} 
Four wheel drives, \\
walking and climbing \\
for 30 minutes-1 hour \\
\end{tabular} & $\begin{array}{l}\text { Visiting for research and } \\
\text { educational purposes }\end{array}$ \\
\hline 11 & $\begin{array}{l}\text { Gua } \\
\text { Harimau }\end{array}$ & $\begin{array}{l}5^{\circ} \mathrm{O} 8^{\prime} 35^{\prime \prime} \mathrm{N} / \\
101^{\circ} \mathrm{O} 4^{\prime \prime} \mathrm{E} \\
\end{array}$ & 133 & $12 \mathrm{~km}$ & $\begin{array}{l}\text { Four wheel drives, } \\
\text { walking for } 30 \\
\text { minutes - } 1 \text { hour } \\
\end{array}$ & $\begin{array}{c}\text { Visiting for research and } \\
\text { educational purposes }\end{array}$ \\
\hline 12 & $\begin{array}{l}\text { Gua } \\
\text { Badak } \\
\text { C }\end{array}$ & $\begin{array}{l}5^{\circ} \mathrm{OO}{ }^{\prime} 51^{\prime \prime} \mathrm{N} / \\
100^{\circ} 59^{\prime} 19^{\prime \prime} \mathrm{E}\end{array}$ & 126 & $13 \mathrm{~km}$ & $\begin{array}{l}\text { Four wheel drives, } \\
\text { walking and climbing } \\
\text { for } 10 \text { minutes }\end{array}$ & $\begin{array}{l}\text { Visiting for research and } \\
\text { educational purposes }\end{array}$ \\
\hline
\end{tabular}

*m.a.s.l = meters above sea level

Whilst, difficult to access geosites are located quite far from the main road and only reachable by four wheel drives. They also required the visitors to climb and walk for some times with proper attires and tools. Gua Gunung Runtuh, Gua Teluk Kelawar, Gua Harimau and Gua Badak C fall in this category (Figure 4, see Table 1).

\section{Bukit Bunuh}

The first geosite is located at Bukit Bunuh area, an open-air site that has provided enormously significant geological and archaeological data contributing directly to our understanding of the palaeoenvironment and early human cognitive behaviour and 
A Geotouristic Itinerary of Geosites: A Proposal for Geotourism and Archaeotourism Development of Lenggong Valley, Perak, Malaysia

culture through their use of stone tools. Bukit Bunuh perhaps the most famous and most visited geosite in the Lenggong Valley as the highest point is over 180 meters above sea level covering area of $4 \mathrm{~km}^{2}$ wide. This geosite is situated in an oil palm estate at latitude $5^{\circ} \mathrm{O} 430^{\prime} \mathrm{N}$ and longitude $100^{\circ} 58^{\prime} 34^{\prime \prime} \mathrm{E}$. It is reached about $4 \mathrm{~km}$ starting from the federal highway (Route 76) exit to Lenggong Archaeological Museum and located approximately $10 \mathrm{~km}$ from the Lenggong Town and accessible by motorbike and/ or four wheel drives. On the top of this central uplift, we can observe both east and west granite bodies which significantly beautify the area. An additional reason for the stop is the fact that it bears the geological scars of meteorite impact which have been dated as 1.83 million years ago by a fission-track method in Japan Geochronology Laboratory (Saidin, 2012b). The medium size of meteorite impact crater at Bukit Bunuh measures approximately $3.45 \mathrm{~km}$ in diameter with $0.7 \mathrm{~km}$ in depth (Nur Khairunnisa et al., 2007). At Bukit Bunuh site, more than 10,000 surface suevite rock associated with the hypervelocity impact has been counted within the impact, having been unearthed as a result of agriculture activities.

A new stratigraphic unit known as Bukit Bunuh Complex, dated as 1.83 million years ago by a fission-track method in Japan Geochronology Laboratory (Mokhtar, 2012a) was found in Bukit Bunuh area. Drilling data shows granite was impacted and suggested as meteorite impact occurrences and all blocks and granite have been formed or deformed by the impact to form this new stratigraphic unit. This area consists of suevite rocks, partially to completely molten rock, polymict impact breccias, impact granite and sedimentary rocks. Suevite can be formed only at high temperature and pressures from natural stones of the area suggest that meteorite impact occurred at Bukit Bunuh area (Kamal Roslan et al., 2012). Apart from the natural rocks material, stone tools were also found among the scattered rocks on the surface (Figure 5). A greater significance of Bukit Bunuh emerged in 2007, when a metaquarzite hand axe embedded in a suevite boulder was found among the surface artefacts. This hand axe is the oldest or among the oldest so far discovered outside Africa. A date of 1.83 million years ago was obtained which give rise to the astonishing revelation that the area was occupied by early humans at such early date.
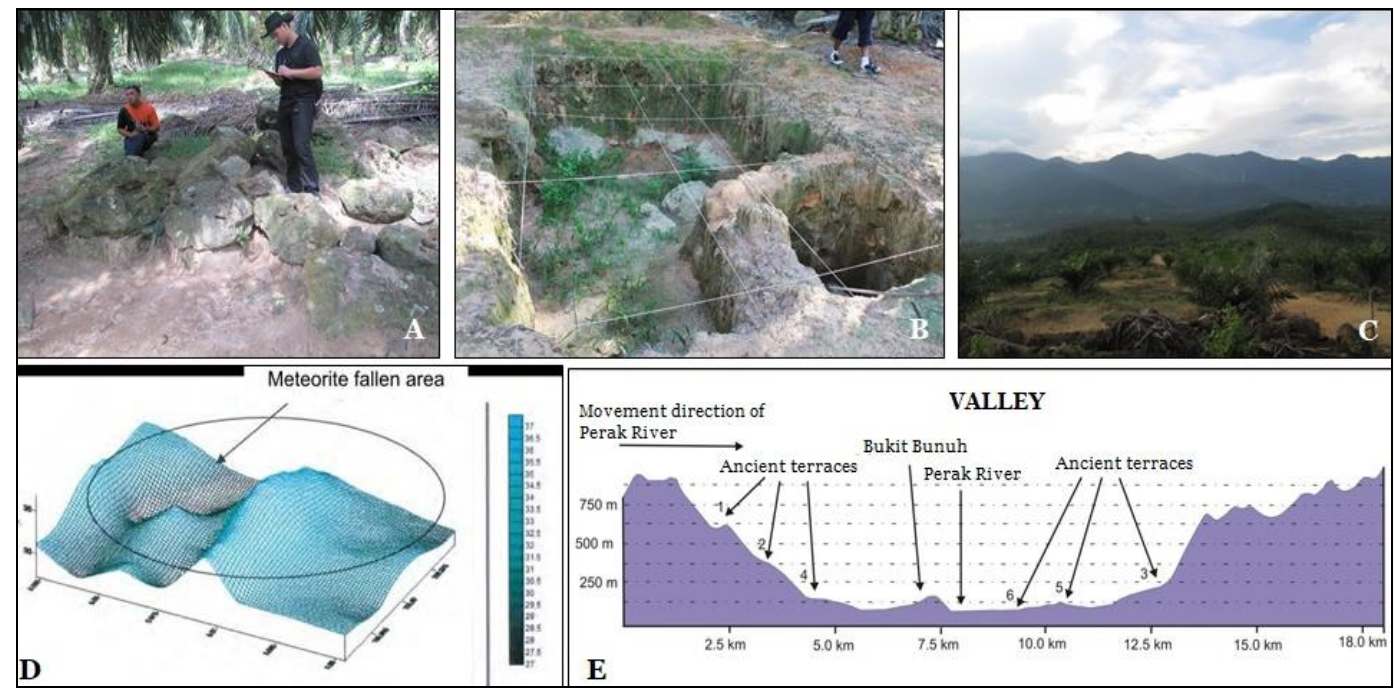

Figure 5. (A) Scattered suevite rocks in Bukit Bunuh area, (B) The excavation trenches in Bukit Bunuh, (C) Panoramic view from the top of Bukit Bunuh facing to the west (Bintang Granite),

(D) Geophysical anomalies illustrate a meteorite impact crater in Bukit Bunuh,

(E) The medium size of meteorite impact crater at Bukit Bunuh measures approximately $3.45 \mathrm{~km}$ in diameter with $0.7 \mathrm{~km}$ in depth. (Source: Department of National Heritage, 2011) 
Given that the hand axe had to be present prior to the meteorite impact, human occupation of the site must have predated this impact. Therefore, this site would have been occupied by human earlier than 1.83 million years ago (Department of National Heritage, 2011). This hand axe is a bifacial symmetrically flaked pebble tool made from metaquartzite with a convex bottom having its sides converging to the top to end in a sharp point $20.3 \mathrm{~cm}$ away. Approximately the top fifth of the tool had broken off but it remained attached in the suevite. The sharp end is probably the result of damage that happened either during manufacture or from use. At its broadest, the hand axe is $10.8 \mathrm{~cm}$ and this occurs approximately $9 \mathrm{~cm}$ from the convex end thus it followed the classical tear-shaped template often referred to as the Acheulean or Mode II (Figure 6). Related activity can be done here is limited to visiting for research and educational purposes only. In terms of complementary facilities, basic facilities such as on-site interpretation boards, public toilets, parking space and pedestrian walkways will be provided in nearer future.

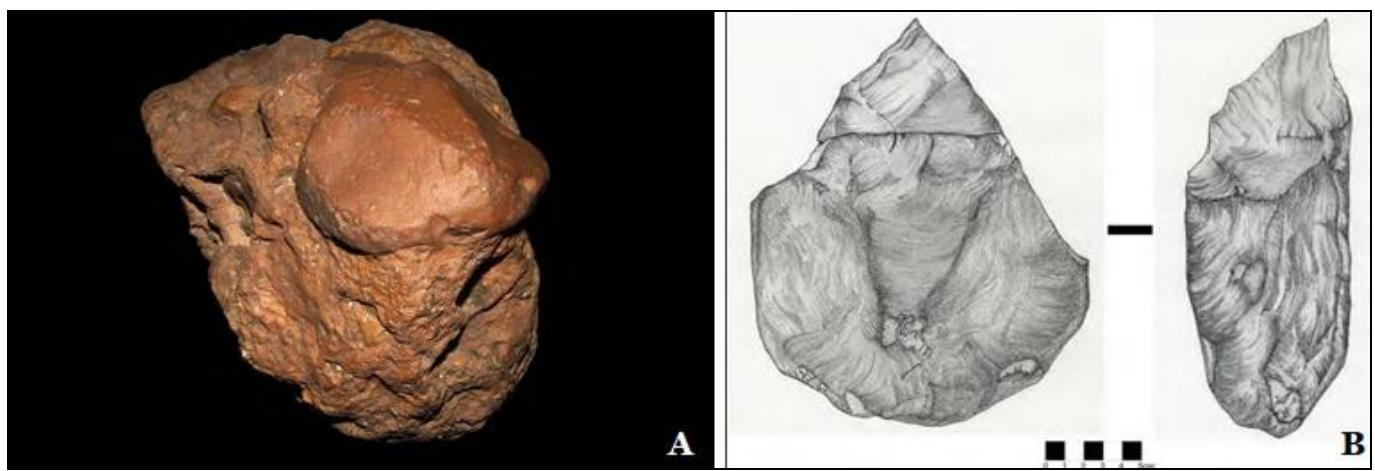

Figure 6. (A) A hand axe embedded in suevite rock. (B) A drawing of 1.83 million years metaquarzite hand axe based on CT scan. Source: Department of National Heritage (2011)

\section{Kota Tampan}

The Kota Tampan site is situated in an oil palm estate at latitude $5^{\circ} 03^{\prime} 18^{\prime \prime} \mathrm{N}$ and longitude $100^{\circ} 58^{\prime} 25$ ” E, about $1 \mathrm{~km}$ apart from Bukit Bunuh site and $12 \mathrm{~km}$ from Lenggong Town. The Kota Tampan site is made up of excavation trenches grouped as KT 1987, begun in 1987 and KT 2005, begun in 2005. KT 1987 is located at the elevation 72-76 meters above sea level while KT 2005 is located higher at the elevation 76-101 meters above sea level. It can be reached by any kind of transportation including small vehicles, car and bus. The two sites are 60 meters apart in a roughly north-south alignment, with KT 2005 occupying the northern end. KT 1987 revealed a thick cultural layer of stone anvils, cores, hammer stones, stone tools and debitage of predominantly quartzite material (Figure 7).

As an undisturbed Palaeolithic stone tool workshop, the association of artefacts such as raw materials, finished and unfinished tools and tool-making debris are clearly visible. This proved to be a rare and significant in-situ stone tool workshop from the Palaeolithic period. The stone assemblages uncovered show that the Palaeolithic inhabitants of Kota Tampan had a good understanding of the raw materials (quartzite and quartz) and knew how to produce type of tools needed that would be the most economic and efficient in terms of their manufacture and use, that is, they were forming a mental template for stone tools (Department of National Heritage, 2011). The assemblage of artefacts found at this site has revealed and made possible the identification and classification of multiple tool types with specialised functions, indicating a lithic technology in South-East Asia as sophisticated as anywhere else in the world. As such this 
A Geotouristic Itinerary of Geosites: A Proposal for Geotourism and Archaeotourism Development of Lenggong Valley, Perak, Malaysia

site is an important global reference site for Palaeolithic stone tool-making. However, no human fossils have been found at the site, so there is lively debate about whether the tools were made of pre-modern Homo erectus or by Homo sapiens. There is no doubt the site is and will remain a site of international importance in the big debates about the origin or our species. Its sudden abandonment was apparently due to a catastrophic event, the Toba mega-colossal volcanic eruption dated by optically stimulated luminescence (OSL) to at least 74,000 years ago, had mingled its volcanic ash with the lithic artefacts recovered at Kota Tampan and this mixture has suggested the 70,000-year date for the lithic workshop sites there (Gatti et al., 2013). Visiting for research and educational purposes as well as demonstration are several activities can be done here. Basic facilities such as on-site interpretation panel, public toilets, prayer room, camp site, boardwalk linkages to all archaeological spot and parking space will be provided in nearer future.
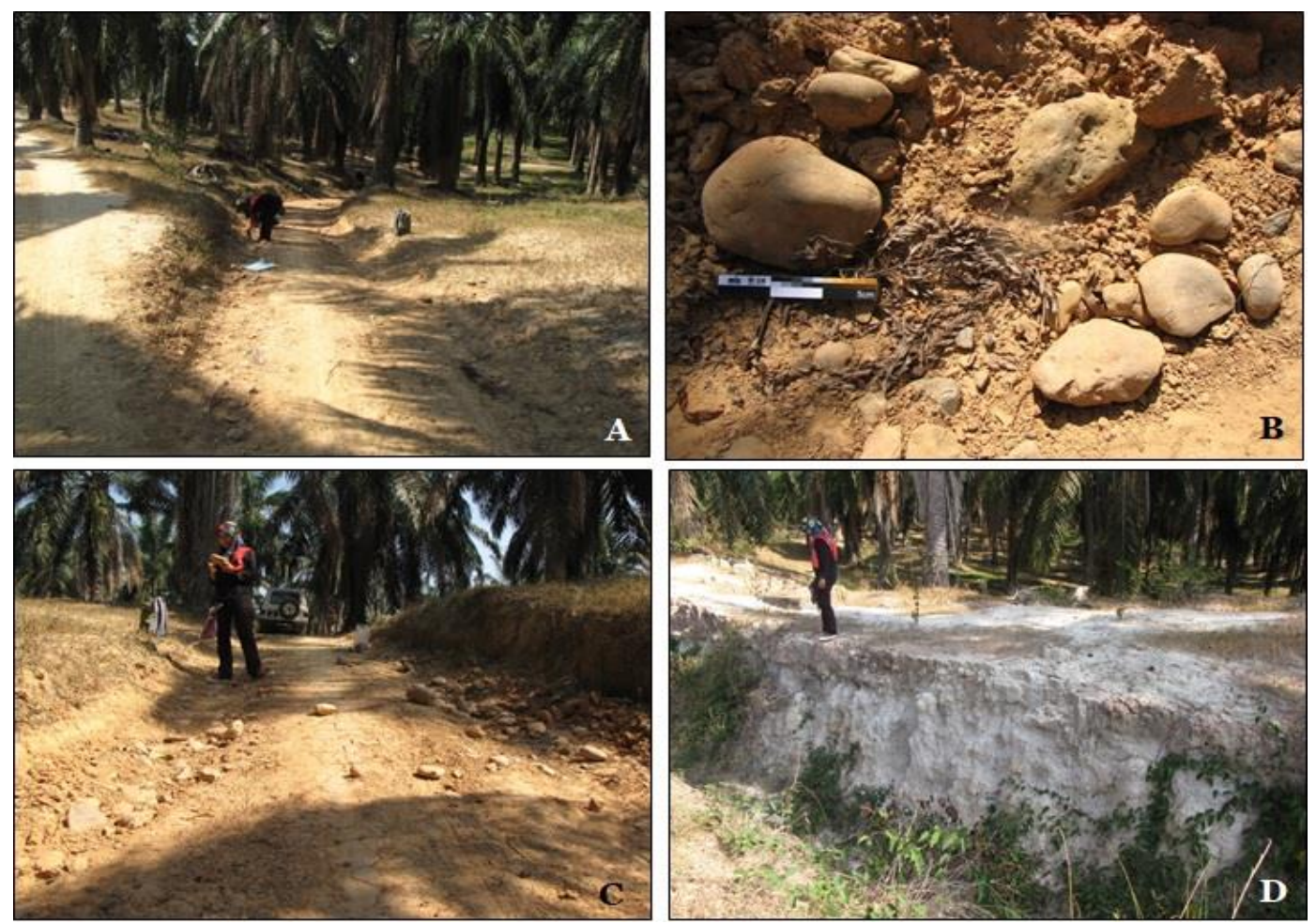

Figure 7. (A) Kota Tampan site located in an oil palm estate, (B, C) Scattered of stone anvils, cores, hammer stones, stone tools and debit age of predominantly quartzite material, (D)

Commingled volcanic ash in the cultural layer which can be attributed to Toba mega-colossal volcanic eruption of 74, ooo years ago cause and date the abandonment of this area

\section{Batu Berdinding}

Batu Berdinding or Batu Dinding geosite located in buffer zone of Cluster 1 of the nominated area in a rubber estate. It is located at latitude $5^{\circ} \mathrm{O} 548^{\prime}$ ' $\mathrm{N}$ and longitude $100^{\circ} 5753$ ” E, at $108 \mathrm{~m}$ above sea level. This geosite located approximately $4 \mathrm{~km}$ from Lenggong Town. It can be reached via trunk road by motorcycle or four wheel drives and located approximately $2 \mathrm{~km}$ away from the entrance (municipal road). Batu Berdinding geosite has been interpreted as a large impact granite rocks formed by meteorite erosion that 
struck and centred at Bukit Bunuh about 1.83 million years ago. The evidence of the rock deformation can be seen clearly on the field. The geology of this area is formed by a metasediment rocks consisting of metaquarzite, filit and slate. Several geological structures such as recumbant folds, overturned folds, asymmetrical folds, shear zones, fault zones, clear poles prove the history of multiple phases that have been encountered by the rocks (Figure 8). This outcrop is well protected and is not threatened because it has not been fully explored by other researchers. This geosite has a very high potential to be developed and preserved for educational purposes. As this geosite is located nearer the ancient Sungai Perak, the evidence of early human activities came from the discovery of stone tools that used river gravels. They produce pebble and flake tools by using anvils, cores and hammerstones and that are crowded with thousands of debitage in the form of chunks, flakes and chips.
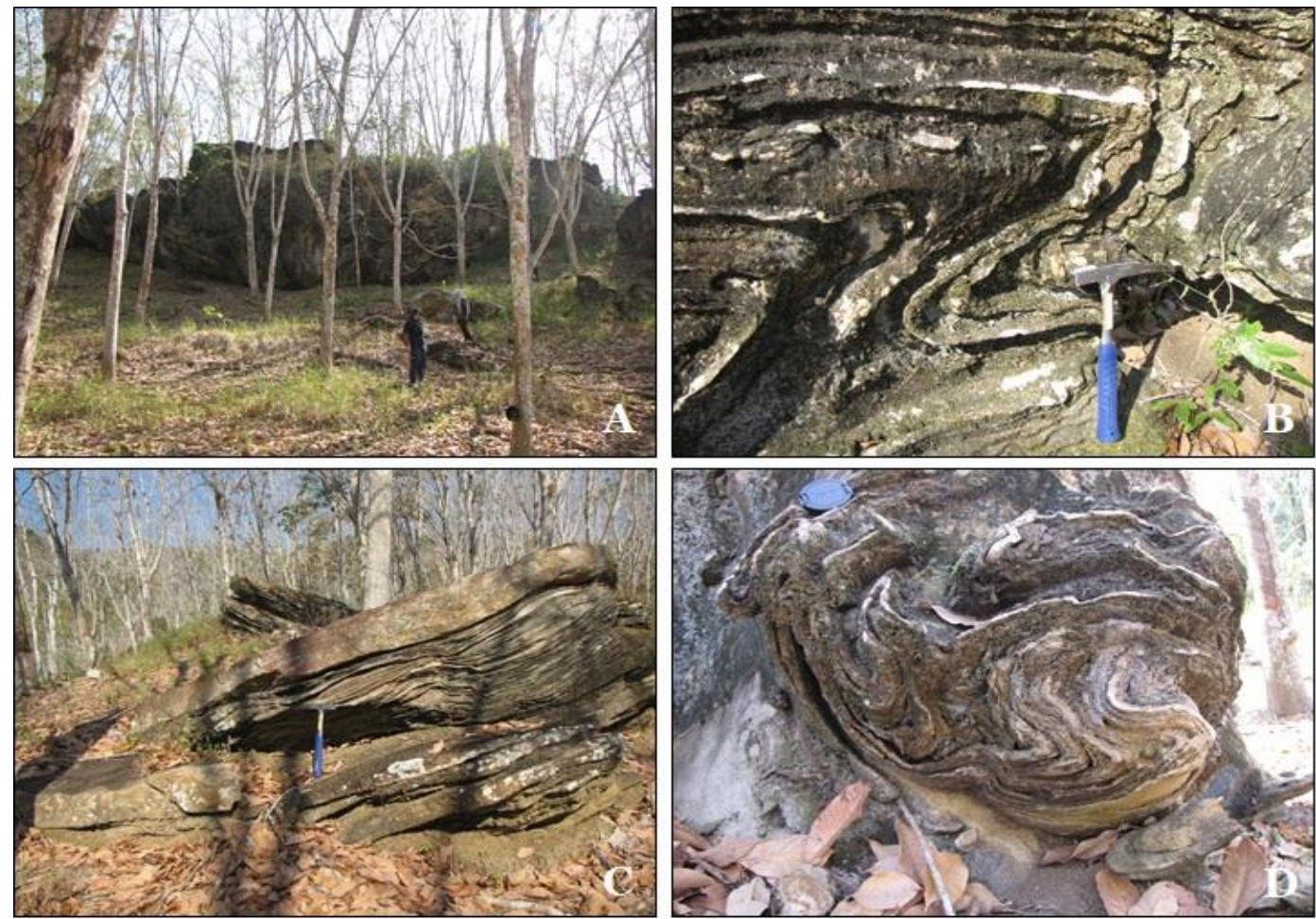

Figure 8. (A) The view of Batu Berdinding outcrop, (B, C, D) Several geological structures such as recumbent folds, overturned folds, asymmetrical folds, shear zones, fault zones and clear poles.

\section{Bukit Jawa}

The Bukit Jawa site in Cluster 2 core zone is an open air site in-situ tool workshop, situated at latitude $5^{\circ} 07^{\prime} 44^{\prime \prime} \mathrm{N}$ and longitude $100^{\circ} 59^{\prime} 34^{\prime \prime} \mathrm{E}$. It is located at 104 metre above sea level at approximately $8 \mathrm{~km}$ away from Lenggong Town. It is situated about 100 meters away from state or municipal roads and accessible by car and bus. The Bukit Jawa site has been interpreted as a Palaeolithic tool workshop site on the shores of an island in a palaeolake now long desiccated. It has been determined from data that any location that is at least 72 metre above sea level and contains river gravel deposits is a potential archaeological site. The site is generally undisturbed with the cultural layer protected by a thick overburden. The richness and extent of the finds from two rescued excavation tranches due to highway 
construction in 1996, suggest that the Palaeolithic population was relatively high, practised a similar lithic technology through time and probably settled on this site because it was a source of the raw material (Department of National Heritage, 2011). Evidence of early human activities come from the discovery of stone tools workshop that used river gravels from the ancient Sungai Perak to produce pebble and flake tools by using anvils, cores and hammer stones and that are crowded with thousands of debitage in the form of chunks, flakes and chips (Saidin, 1993, 2007a, 2007b; Saidin \& Jeffrey, 2007). The technique of tool making using anvils and hammer stones was similar to but not as technologically developed as that uncovered at Kota Tampan. The completed tools appear to be prototypes of Kota Tampan. Generally, they were mostly from quartz, large and crudely produced with large flakes, and reminiscent of middle Palaeolithic tools. Some are so massive that require holding with both hands. Tools were mostly made from locally available quartz, but finds of sandstone tools led to the discovery of a nearby sandstone source at Bukit Suring (in the buffer zone). Since the tools were cruder and there was less understanding of stone lithology, these sites had to be older than Kota Tampan. From a consideration of the stratigraphy and the morphology of the finished products, it was concluded that Bukit Jawa could be relatively dated to 200,000-100,000 years ago (Saidin, 2004, 2007a, 2007b; Saidin \& Jeffrey, 2007). This site is now protected as an exposed representative of the Bukit Jawa cultural layer (Figure 9). Propose activities including visiting, demonstration and fun excavation with the theme "Archaeologist for A Day". Students will be given excavation tools and uniforms for hands-on experience guided by Department of National Heritage. To increase interaction, participants are awarded with junior archaeologist title (certificate). Once the proposed activity matures, the attraction will be scaled-up to be a summer camp program to attract international schools and university students.
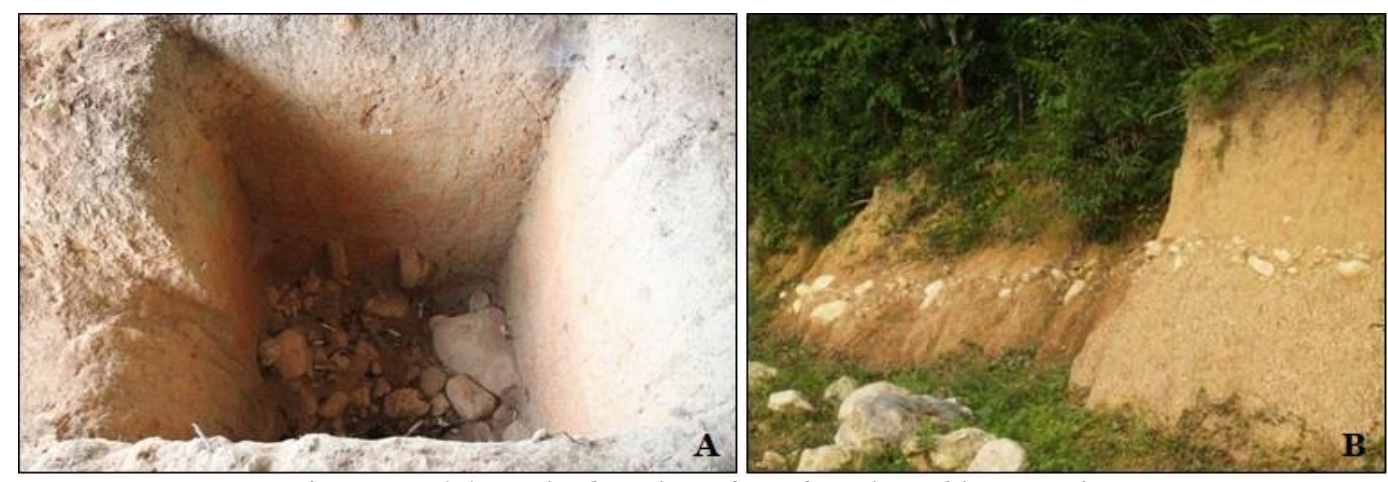

Figure 9. (A) In-situ location of artefacts in Bukit Jawa site.

(B) Abundant quartz as raw material in making stone tools.

\section{Bukit Sapi}

The Bukit Sapi site is located quite far from the other geosites in Lenggong Valley. It is situated outside of Special Area Plan (SAP) boundary at latitude $5^{\circ} 08^{\prime} 48^{\prime \prime} \mathrm{N}$ and longitude $101^{\circ} \mathrm{O} 1^{\prime} 28^{\prime \prime} \mathrm{E}$, approximately $18-20 \mathrm{~km}$ from the Lenggong Town. It can be reached via municipal route A167 from federal highway route 76 . As all the other geosites located at the western side of the Sungai Perak, the Bukit Sapi area is the only site located at the eastern side of this river valley. However, the exposed outcrop at the Bukit Sapi located exactly next to the municipal road and can be reached by motorbike, bus and car. Related activity can be done here is limited to visiting for research and educational purposes only. In general, the entire sections of the valley in Lenggong area, especially lower than 72 
meters above sea level were inundated with whitish to light grey colour materials, known as white soil or rocks by the locals (Figure 10). Essentially, it is volcanic ashes that came from the Toba eruption in Sumatra, Indonesia, about 74,000 years ago. The fresh ashes mostly free of organic material, but at the some places ashes mixed with the soil and clay and burrowing by organism or growth of plants roots. The outcrop is far from the riverbank and the ashes are fresher because they are not exposed too much and less weathering.
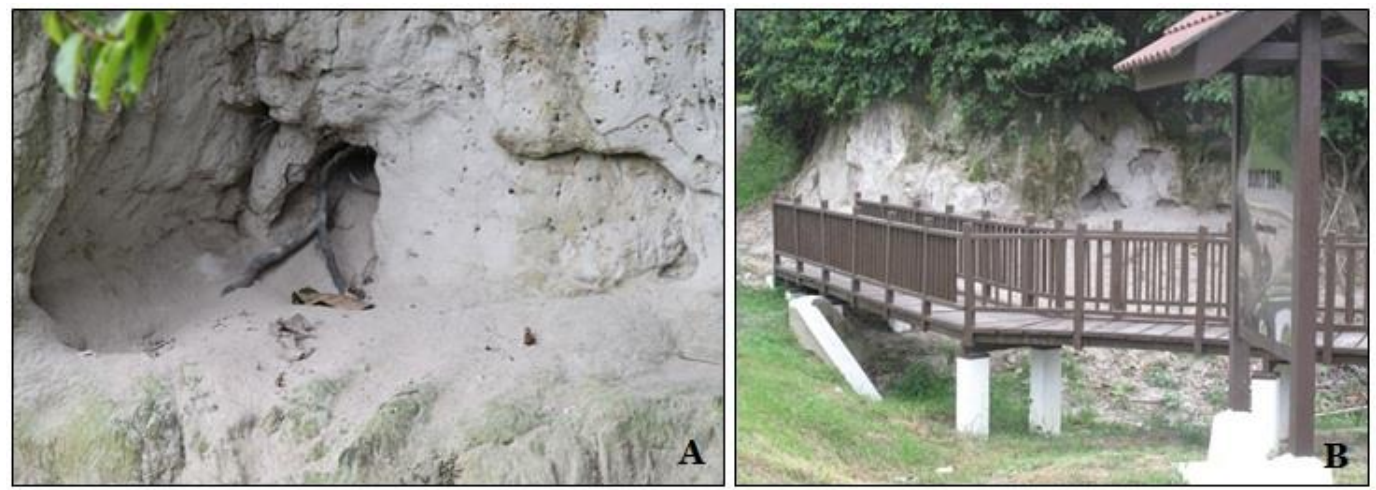

Figure 10. (A) Exposed outcrop of fresh Toba ash deposition in Bukit Sapi area,

(B) Facilities provided include information board and wooden pathways.

For records, the Toba ashes reveal its distribution to the Indian Ocean. The presence of Toba ashes in the peninsular Malaysia was recorded at several locations such as the Sungai Perak valley by Scrivenor (1931), in western Pahang by Richardson (1939, in Selangor by Stauffer (1973) and Stauffer \& Batchelor (1978) and in Baling, Kedah by Debaveye. Foo in 1990 described the ash found in Kuala Kangsar as Cegar Galah volcanic as layer resembling a rhyolite. In 2007, USM has mapped the Toba ash distribution in the Lenggong Valley which is found to be 7-10 meters thick, scattered around $70 \mathrm{~km}$ square. Based on archaeological evidence, the association of stone tools and Toba ash with the Kota Tampan artefacts shows the possibility that this catastrophe affected the extinction of prehistoric society (Department of National Heritage, 2011).

\section{Sungai Perak (River)}

Sungai Perak or Perak River is the longest river in Peninsular Malaysia that flows from Temenggor Lake throughout Lenggong valley before entering Chenderoh Lake. This river extends from the longitude of $5^{\circ} 20^{\prime} 25^{\prime \prime} \mathrm{N}$ to $5^{\circ} \mathrm{OO}^{\prime} \mathrm{O}^{\prime \prime} \mathrm{N}$ and the latitude of $101^{\circ} 10^{\prime}$ $\mathrm{O}^{\prime \prime} \mathrm{E}$ to $100^{\circ} \mathrm{O9}^{\prime} \mathrm{O}^{\prime \prime} \mathrm{E}$. Generally, the total length of Sungai Perak in Lenggong Valley District is $10 \mathrm{~km}$ away. It can be reached via any kind of transportation. Some Sungai Perak winds in short bends within a $6.5 \mathrm{~km}$ wide, NNE trending depression that is flanked by mainly granitic, hilly to mountainous topography. Some geomorphological features occur along the river such as cascades and rapids. The river becomes part of the transportation source for some of the villagers living nearby. A variety of recreational activities can be carried out including boating, caneoing and kayaking. The Sungai Perak with its little islands and tributaries flows through the valley (Figure 11), which is today essentially an agricultural landscape including rubber and palm oil plantations threaded with traditional villages. Geological evidence indicates that the Sungai Perak changed its course at various times, resulting in gravel deposits (Figure 11B), and creating lakes at Lenggong and nearby Lawin and Gerik in the ancient past (Tjia, 1993). A meteorite impact 1.83 million years ago blocked the river and diverted its course. During the period 
A Geotouristic Itinerary of Geosites: A Proposal for Geotourism and Archaeotourism Development of Lenggong Valley, Perak, Malaysia

of much lower sea levels 40,000 years ago the valley was part of a tropical savannah. Over a period of two million years the valley provided gravel suitable for prehistoric stone tool making and limestone caves for shelter (Department of National Heritage, 2011).
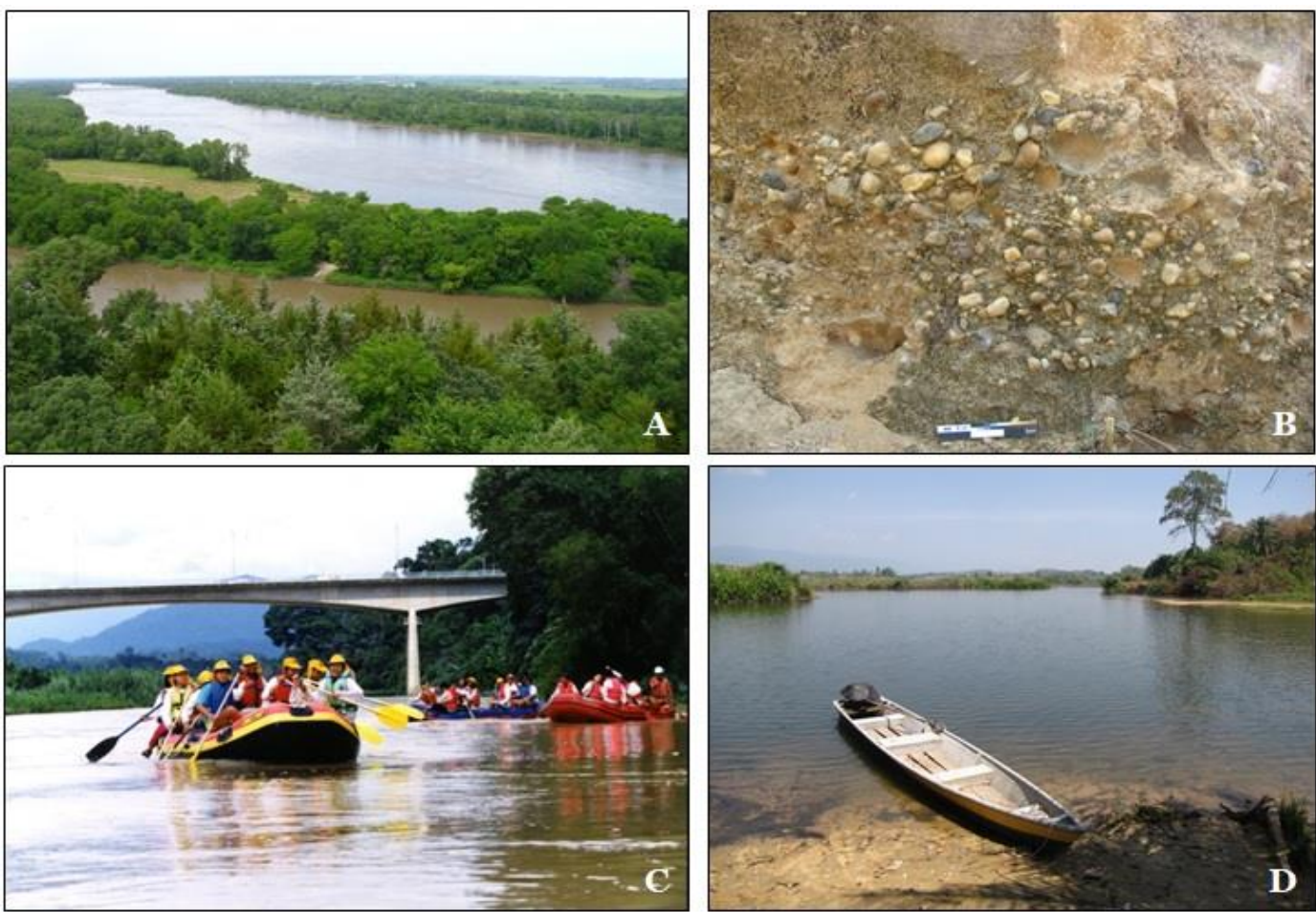

Figure 11. (A) Sungai Perak with its little islands and tributaries flows through the valley, (B) River gravel deposits (C) Leisure activities include boating, canoeing and kayaking, (D) Beautiful views of Sungai Perak

\section{Lata Kekabu}

Lata Kekabu is a beautiful waterfall and a major tourist attraction in this area. It is a part of Bintang Granite and located in Bintang Hijau Reserved Forest at latitude $5^{\circ} 2^{\prime} 41^{\prime \prime} \mathrm{N}$ and longitude $100^{\circ} 56^{\prime} 57^{\prime \prime} \mathrm{E}$ and is approximately $106-130$ meters above sea level. The entrance to the waterfall located exactly next to the federal highway Route 76 (Figure 12a). This waterfall can be reached about $9 \mathrm{~km}$ from Lenggong Town and $1 \mathrm{~km}$ from the entrance by any vehicles including bus. The area surrounded by the tropical rainforest, has been developed as popular recreational area (Figure 12B) and equipped with various facilities and infrastructure such as camping site, public toilets, multipurpose open hall, hanging pathway, praying room, gazebos and parking lot. The river flow at the downstream is very wide but is not so deep that it is suitable for swimming.

Fishing and guided hiking are other possible activities that can be done here. The waterfall also can be enjoyed all year round. Lithologically, Lata Kekabu is part of the Bintang Granite. Based on the field observation, this area is composed of porphyritic granite. The grey and pink colour porphyritic granite is because of the existence of alkali feldspar as the phenocryst. Muhammad Farhaan (2013) stated that the rock diversity in the site includes biotite-porphyritic granite, porphyritic granite, microgranite, quartzite, schist and granite. The uniqueness of this cascade is the existence of xenolith of different 
sizes in the large body of granitic rocks (Figure 12c). Other geological features include joints and faults. The visible joints on the rock wall form a beautiful setting for the gushing water. In addition, veins can be seen in some parts of the cascade.
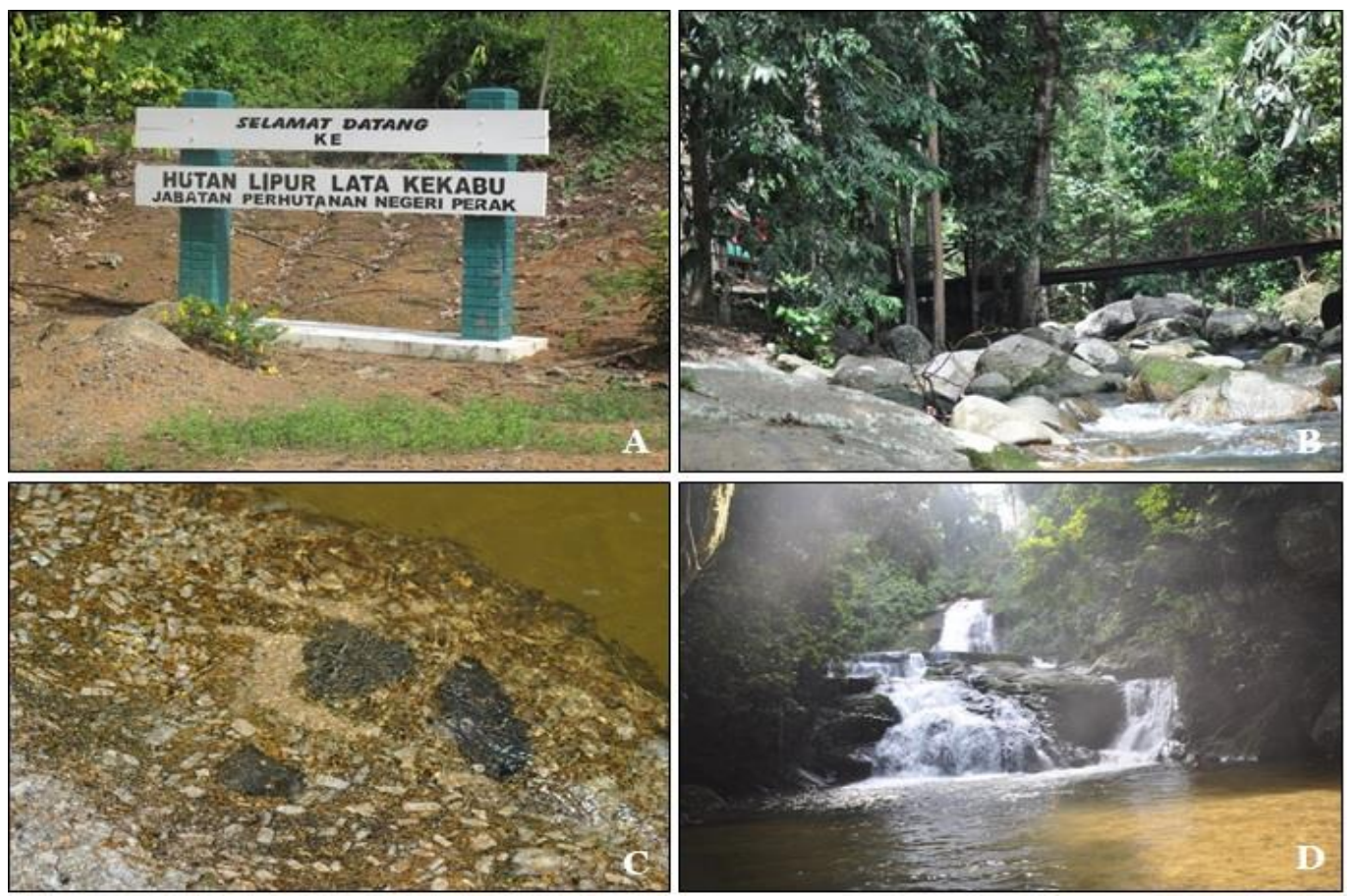

Figure 12. (A) Signage to Lata Kelabu located exactly next to the federal highway Route 76 , (B) The area is surrounded by the tropical rainforest, has been developed as popular recreational area and equipped with various facilities and infrastructure such as hanging pathways and gazebo, (C) The existence of xenolith of different sizes in the large body of granitic rocks, (D) Scenic view of the upper area of Lata Kekabu

\section{Gua Kajang - Puteri - Asar}

The Bukit Kepala Gajah massive limestone, located in Cluster 2 is a large outcrop that occupies an area of six square kilometers with a summit 258 meters above sea level. The topography of the hill consists of steep-to vertical walls with rounded tops and contains more than 20 caves and rock shelters (Department of National Heritage 2011). Among four of the excavated caves, three of these revealed prehistoric burials - Gua Gunung Runtuh, Gua Teluk Kelawar and Gua Kajang. Lying approximately $6 \mathrm{~km}$ from the town of Lenggong Valley, Gua Kajang is a natural limestone tunnel through the Bukit Kepala Gajah massive limestone comprising three caves including Gua Asar and Gua Puteri. It is located at latitude $5^{\circ} \mathrm{O} 7^{\prime} 36^{\prime \prime} \mathrm{N}$ and longitude $100^{\circ} 58^{\prime} 26^{\prime \prime} \mathrm{E}$ and is approximately 72 meters above sea level. Gua Kajang is about $2 \mathrm{~km}$ by trail from Gua Gunung Runtuh. It is also easily accessible by vehicles from the surrounding smallholdings. The cave is oriented north-south and divided into three small portions: the front cave, back cave and a small chamber adjacent to the back cave. The front cave is the shelter facing north and the cave mouth is about $25 \mathrm{~m}$ in length (Figure 13). Two human burials excavated there in 2007 were dated to in the vicinity of 10,000 and $7,800 \mathrm{BP}$, one of which was distinguished as having Australomelanesoid features, which is reliable with Perak Man and other late Palaeolithic skeletons revealed so far in the Lenggong Valley (Zuraina et al., 2005). 
A Geotouristic Itinerary of Geosites: A Proposal for Geotourism and Archaeotourism Development of Lenggong Valley, Perak, Malaysia
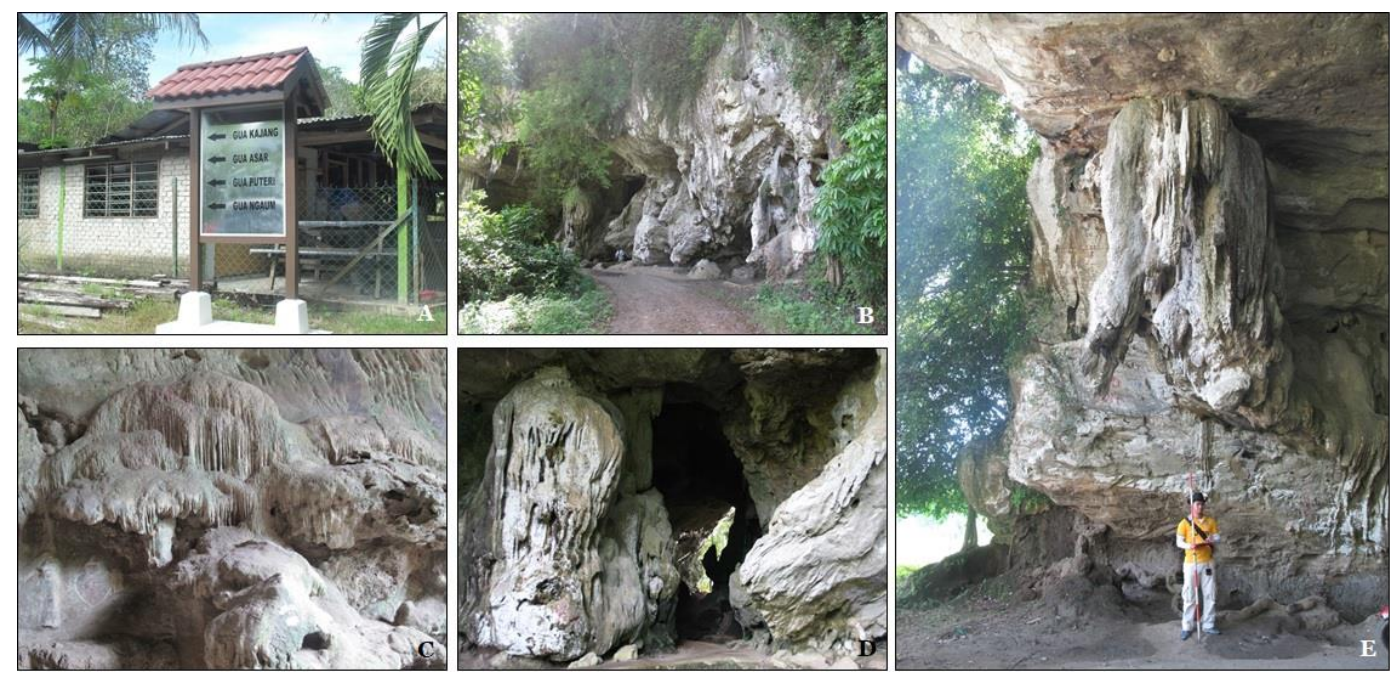

Figure 13. (A) Signage to Gua Kajang-Asar-Puteri, (B) The front view of Gua Kajang,

(C, D, E) Interesting speleothem formation in Gua Kajang

The floor of the tunnel is interspersed with deep man-made holes over which unrefined wooden stages had been laid to provide passage for wheeled vehicles between the two mouths of the tunnel. According to local knowledge the tunnel was utilized as a part of the current past as a thoroughfare for steed or buffalo-drawn carts. This cave has also been featured in a local movie as one of their shooting area. Earlier it had been mentioned that caves in the massive limestone at Lenggong Valley probably emerged from beneath water and accumulated soil on their floors only at the end of the Pleistocene or some 10,000 - 12,000 years ago. It would be about this time that man in the Lenggong Valley began to seek shelter in these caves as hunting camp, habitation or burial site.

Archaeological research in Lenggong Valley first emerged in 1917 when Evans (1918) unearthed fragments of human bones in Gua Kajang. Further analyses done by Duckworth (1934) on these human bone fragments suggested that prehistoric man of Gua Kajang may have had an ancestral link to the Australian aborigines. In 2007, Goh (2008) uncovered two further burials, GK 1 and GK 2, which were dated to between 10,000 and 7,800 years ago. Two in-situ human burials (GK 1 and GK 2) from two different cultural layers were also uncovered. These burials were partially disturbed but the skeletons in them remained intact as indicated by the bone articulation and burial goods. GK 1, a 50\% complete female skeleton, was laid face down and in a flexed position (prone flexed) with both legs folded up to the chest while both arms were folded up to the shoulder.

Radiocarbon dates derived from the associated shell samples suggested a Late Palaeolithic age of 10,820 \pm 60 BP (Beta-227446) for GK 1 . GK 1 had a stature between $155 \mathrm{~cm}-163 \mathrm{~cm}$. Approximately 1 metre away and southeast of GK 1, the leg bones of another human skeleton associated with food remains and stone tools were also uncovered at a depth of $70-80 \mathrm{~cm}$ and with a radiocarbon date of $7,890 \pm 80$ (Beta227445). The original position of GK 2 was unfortunately indeterminated because it had been badly disturbed by guano collectors. The gender and the stature of GK 2 could not be determined due to the absence of indicators. The skeletal remains of GK 1 and GK 2 were identified as adults but their ages at death could not be determined.

Palaeoanthropological studies show that GK 1 bears Australomelanesoid features, which is quite consistent among the late Palaeolithic skeletons uncovered so far in the 
Lenggong Valley. Gua Asar is located within the Bukit Kepala Gajah massive limestone. It is located at latitude $5^{\circ} 07^{\prime} 56^{\prime \prime} \mathrm{N}$ and longitude $100^{\circ} 58^{\prime} 80^{\prime \prime} \mathrm{E}$, sits $78 \mathrm{~m}$ above sea level and is the neighbour to Gua Kajang. The cave bears an interesting limestone formation (Figure 14). The Asar Cave has yet to be carried out archaeological research in detail. It can be reached within 30 minutes walking via broadwalk from Gua Kajang.
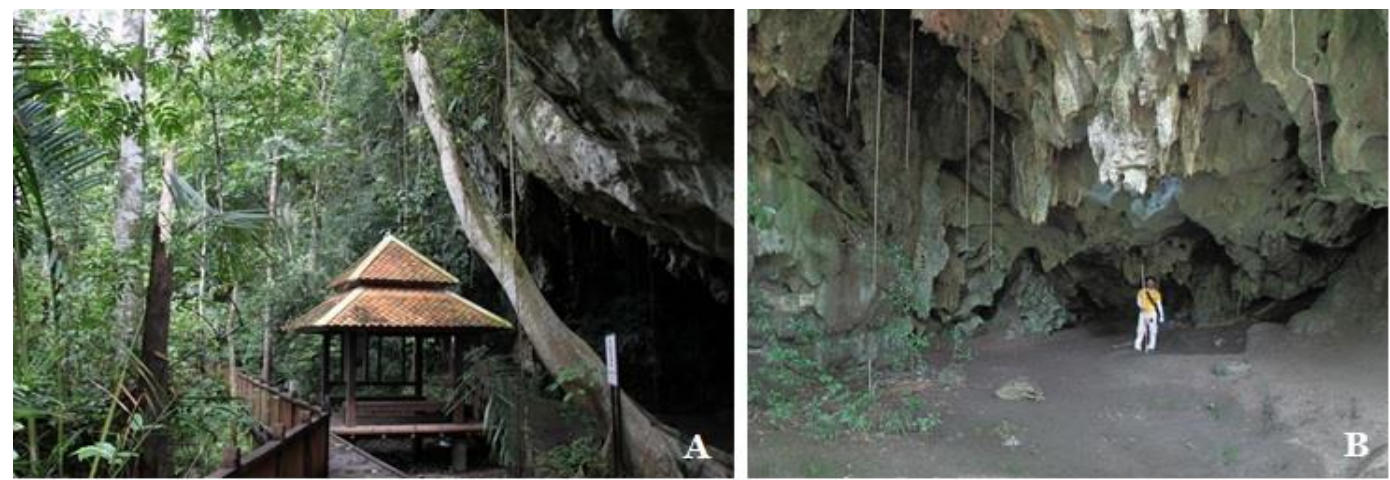

Figure 14. (A) Gazebo and information panel in front of Gua Asar, (B) Gua Asar site
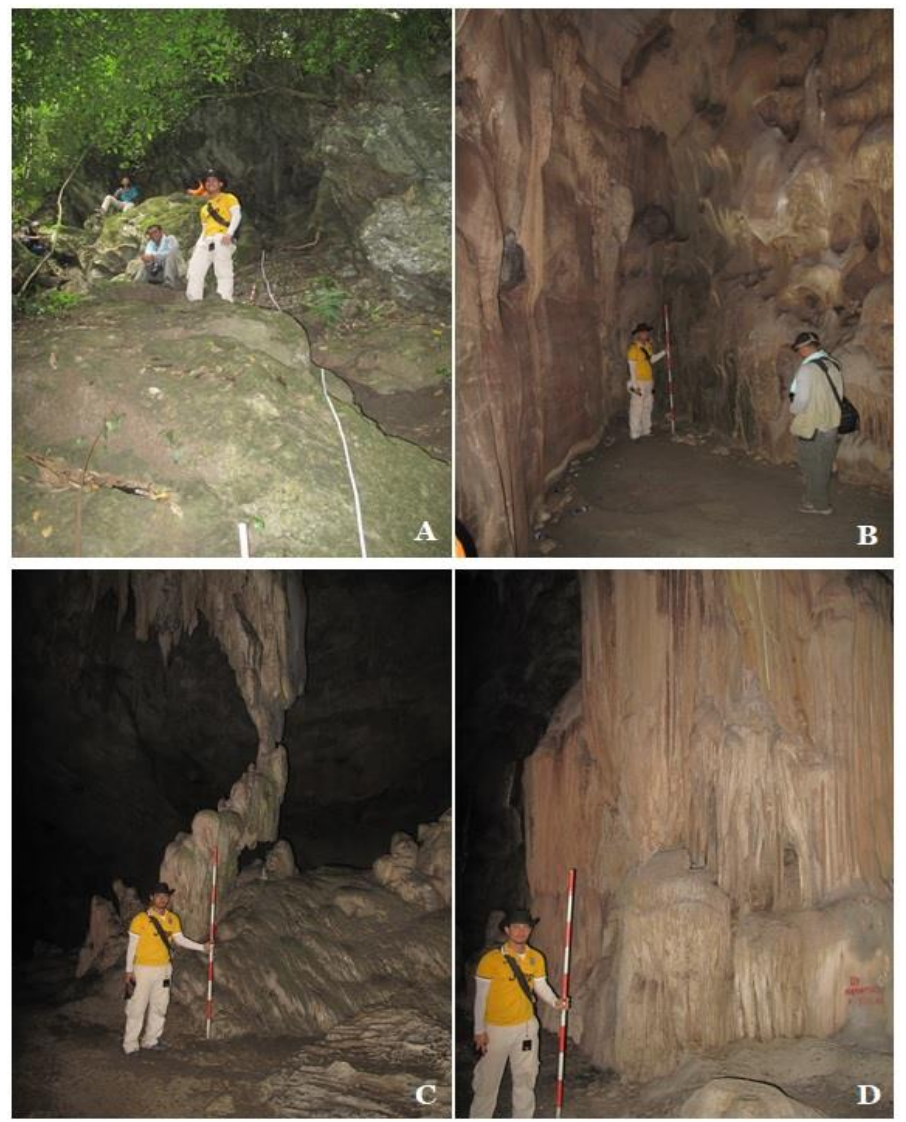

Figure 15. (A) Visitors are required to climb for a 10-15 minutes to reach Gua Puteri, (B, C, D) Interesting limestone formations inside Gua Puteri 
A Geotouristic Itinerary of Geosites: A Proposal for Geotourism and Archaeotourism Development of Lenggong Valley, Perak, Malaysia

Gua Puteri is also a cave within Bukit Kepala Gajah massive limestone, located at latitude $5^{\circ} \mathrm{O} 7^{\prime} 53^{\prime \prime} \mathrm{N}$ and longitude $100^{\circ} 58^{\prime} 82^{\prime \prime} \mathrm{E}$ and at an elevation of $94 \mathrm{~m}$ above sea level. Visitors are required to walk for 40 minutes from Gua Kajang and climbing for 15 minutes to reach the cave mouth. Interestingly, the limestone formations inside the cave can be taken for sculptures representing a map of Malaysia, a frog, a couple of wedding platform, an elephant's head, a mosquito net and others (Figure 15). Local legends have it that these were once alive but were calcified by an evil spirit called Sang Kelembai. Be as it may, geologically speaking, these are simply stalactites and stalagmites in their amazing varieties as they grew with the time into the available spaces. These caves are also the habitats for bats and doves. The guano digging activities have been stopped since the area was nominated as World Heritage Site. Main activities included visiting for research and educational purposes, cave exploration and trekking. In terms of amenities, on-site interpretation boards, parking space for 3-4 vehicles, gazebos and wooden broadwalks are available.

\section{Gua Gunung Runtuh}

Gua Gunung Runtuh in Cluster 2 core zone with difficult access category, is located at latitude $5^{\circ} 07^{\prime} 3$ " $\mathrm{N}$ and longitude $100^{\circ} 58^{\prime} 3$ ” E, approximately 124 metre above the sea level and 75 meters above surrounding secondary rainforest. There are three entrances to the cave, of which the most convenient approach is through the south entrance. This cave located $8 \mathrm{~km}$ away from Lenggong Town and is part of small hamlet, Kg Gelok, accessible by four wheels drives or a footpath that takes half an hour to traverse and then a 15-minute climb (Figure 16). It is currently monitored and maintained by the Department of National Heritage. This cave has three chambers. The main chamber opens to the north-east.
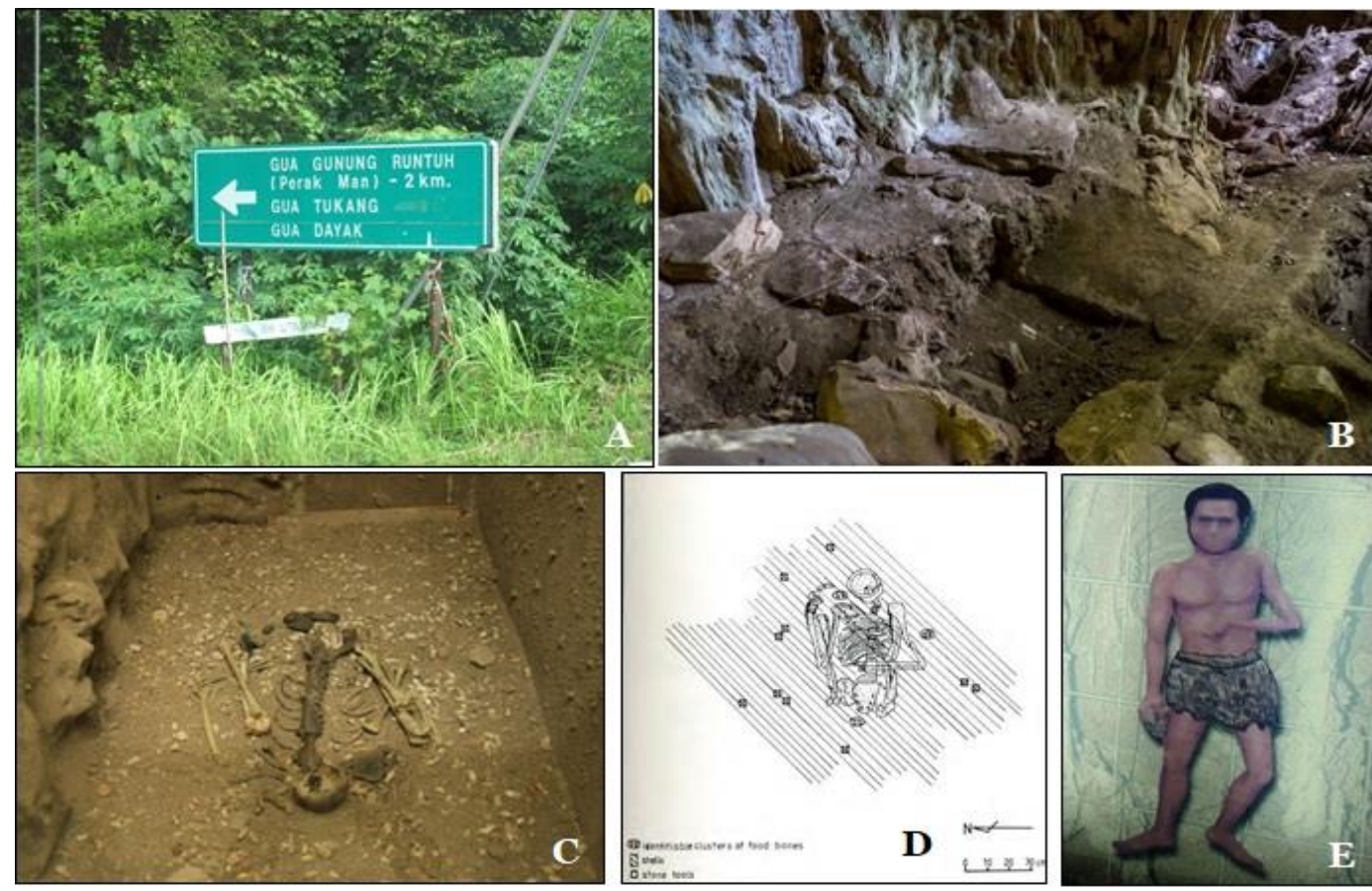

Figure 16. Signage to Gua Gunung Runtuh, (B) Excavation location of Perak Man at Gua Gunung

Runtuh, (C) Preserved original skeleton of Perak Man can be seen in Lenggong Archeological Museum, (D) The burial area of Perak man and the associated mortuary objects, (E) An artist impression of the perak man with congenital deformity. Source: Department of National Heritage (2011) 
Two smaller openings to the west and south-east have been blocked by rock falls. Gua Gunung Runtuh is dry and the cave is lit by sunlight coming through the north entrance. Boulders of various sizes and fragments of stalactites and stalagmites lie scattered on the cave floor (Zuraina, 1996; Zuraina et al., 2005). Gua Gunung Runtuh was first excavated in 1990 by a team from USM Malaysia headed by Zuraina Majid. The excavation at Gua Gunung Runtuh suggests that man occupied this cave for habitation and burial purposes, beginning about 13,000 years ago until 2,600 years ago (Zuraina, 1994, 1996; Zuraina et al., 2005). This 1990 excavation significantly placed the prehistory of Malaysia on the world archaeological map with the discovery of Southeast Asia's oldest most complete human skeleton - the Perak Man, radiocarbon dated to $10,120 \pm 110 \mathrm{BP}$ (Beta-38394). During the 1990 excavation, the first hint of a skeleton as a faint view of its long bone and part of the skull at the $60-70 \mathrm{~cm}$ spit in Trench A2 but it was only at the $90-100 \mathrm{~cm}$ spit that the rest of the skeleton revealed itself. The almost complete skeleton, missing only some bones such as metatarsals, costa and parts of the face, was found laid down in an east-west orientation, and with its head slightly inclined to the right. The right arm was folded up to the shoulder while the left arm was flexed with the hand placed on the stomach and both legs were folded over the chest (Zuraina, 1994; Zuraina et al., 2005). The skeleton was named Perak Man to honour the state that it was discovered in.

Physical examination of the skeleton was first conducted on-site and later after removal, in the laboratory for analyses. Gender was determined by an examination of the pelvis, sacrum and the skull. The pelvis including the pubic bones is not well preserved and so the sub-pubic angle is not clear. However, the narrow and shallow pre-auricular sulcus and the non-spacious and funnel-shaped pubic basin are all strong male characteristics. Furthermore, by examining the skull, male characteristics can be supported by the large occipital bone, mastoid processes and teeth. The chin of the mandible is square whereas it should be more rounded with a point at the midline if it had belonged to a female. Further support for a male gender comes from the examination of the sacrum. It is curved and in its dimensions, it is longer than it is wide (Department of National Heritage, 2011). Based on laboratory measurement of bone lengths and using a formula developed from Indonesian skeletons, the stature of Perak Man was estimated at about $154 \mathrm{~cm}$. Perak Man has a long head and a narrow face. These and other traits observed not only in the skull but also in other bones such as the humeri, femora and tibiae suggest that the affinity is Australomelanesoid, a race occupying the western part of the Indonesia archipelago and continental Southeast Asia at the end of the Pleistocene and early Holocene but now largely confined to east Indonesia, Melanesia and Australia (Department of National Heritage, 2011). Their association with the observed volarly and radially curved phalanges, shorter lower arm bones and compensatory scoliosis of the spine suggest a genetic malformation known as Brachymesophalangia type A2, an extremely rare condition even in present human population. The presence of such a deformity in a prehistoric population has not been recorded before. Thus, the Perak Man is the first ever recorded instance of Brachymesophalangia type A2, making the Perak Man important for the understanding of human medical history. Current knowledge about prehistoric lifespan suggests that Perak Man lived longer than the average duration of life for his community. He lived in a community where the human lifespan averaged 20-30 years. The Perak Man died at a relatively ripe old age of $40-45$ years. Thus, it is interesting to speculate on the possible cause of his death with relevance to his age. At such an old age, he would not have been required to hunt for food or perform heavy-duty jobs for day-to-day living. He would certainly have been an old respected figure in his community probably cared for by all around him because of his status as an elder (or even a shaman), and his 
A Geotouristic Itinerary of Geosites: A Proposal for Geotourism and Archaeotourism Development of Lenggong Valley, Perak, Malaysia

knowledge on survival, hunting, gathering, healing, and other aspects of a Palaeolithic way of life. Faunal remains, shells and stone tools were found together with the skeleton in the grave. A total of $1,261 \mathrm{~kg}$ of animal bones and teeth were collected. Their fragmentary nature made it mostly impossible to identify to species level. The few identifiable ones came from the wild pig (Sus scrofa), the monitor lizard (Varanus sp.), the deer, Cervus unicolor, monkeys (Macaca sp.), the tortoise and possibly the leopard, gibbon and the kijang species of deer. Most (76.8\%) were found at what would have been the bottom of the grave and distributed around the left arm, right shoulder, and feet. Some animal bones were found among the right finger bones. A small portion of the remains (7.7\%) bore traces of charring. There were altogether 2,878 shells collected from grave at different depths. Most (82\%) were collected from the basal level and immediately above the body. The shells could be separated into small, medium and large animals. Medium shells were the most prevalent (42.7\%). The large ones made up 18.5\% and were found mostly between and just below the skeleton. The Perak Man skeleton, a key icon in Malaysia archaeology, remained almost intact for more than 11,000 years in GRC. The Perak Man survived for such a long time mainly because he was buried in a naturally controlled cave environment with a relatively cool and constant temperature of $24^{\circ} \mathrm{C}$ and dry slightly alkaline soil condition that was suited for bone preservation. The dryness of the cave interior has slowed down natural deterioration caused by plant growth and rock slides, and kept the population reduced. The trench from which Perak Man was excavated remains in place and has not been back-filled so as to be a record its original location. In 2008, the Perak Man was inscribed as a National Heritage object in the National Heritage Register (Gazette No. P.U [B] 235), followed by the site of Gua Gunung Runtuh (Gazette No. P.U [B] 494) as a National Heritage Site in 2009. This can be expected to lead to adequate management and conservation. Related activity can be done here is strictly limited to visiting the outside hills and excavation areas only. In terms of complementary facilities, basic facilities such as on-site interpretation boards with good storytelling and canopy walks will be provided in nearer future.

\section{Gua Teluk Kelawar}

Associated with the GTK 1 burial were stone tools, animal bones and Brotia shells that are similar to the mortuary goods of Perak Man and GK 1.
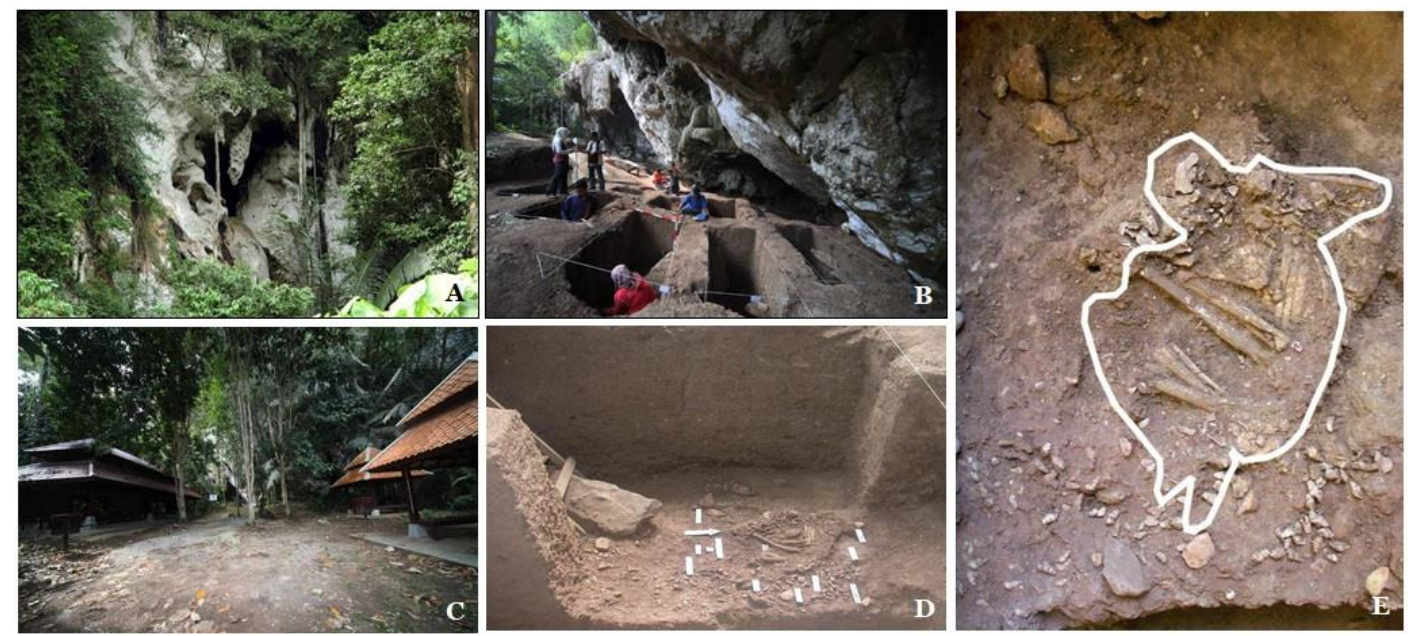

Figure 17. (A) The front view of Gua Teluk Kelawar, (B) The excavation site in Gua Teluk Kelawar, (C) Facilities in Gua Teluk Kelawar, (D) Partially disturbed human burial was uncovered, (E) The skeleton known as GTK 1, was found buried in a tight foetal position. Source: Department of National Heritage (2011) 
An associated shell sample from the burial provided a radiocarbon date of $8,400 \pm$ 40 BP (Beta-193000). GTK 1 was considered female based on measurement of the femoral and humerus heads, the upper edge of the eye orbit and on the lack of prominence of the supraorbital ridge. From a fibula measurement, she was between 143 and $151 \mathrm{~cm}$ tall. She probably died at an age of 45 to 50 years. A palaeoanthropological study showed that GTK 1 was of Australomelanesoid stock, just like the Perak Man (Bulbeck and Zuraina, 2007). Visiting for research and educational purposes is the only activity can be done here. Basic facilities such as on-site interpretation panel with good design and contents, enhance existing buildings into a mini interpretation centre and hanging pathsways to observe the excavation site will be provided in nearer future.

\section{Gua Harimau}

Gua Harimau is a massive limestone in core zone area, containing prehistoric cemetery located approximately $12 \mathrm{~km}$ from the town of Lenggong. It is situated at latitude $5^{\circ} 08^{\prime} 54^{\prime \prime} \mathrm{N}$ and longitude $100^{\circ} 58^{\prime} 37^{\prime \prime} \mathrm{E}$ and is about 133 meters above sea level and accessible by four wheel drives as well as walking and climbing for 30 minutes -1 hour. Gua Harimau is a large cave (Figure 18) with a well-lit entrance located in the south, measuring about $28 \mathrm{~m}$ in length and $20 \mathrm{~m}$ high (Chia \& Zolkurnian, 2005).
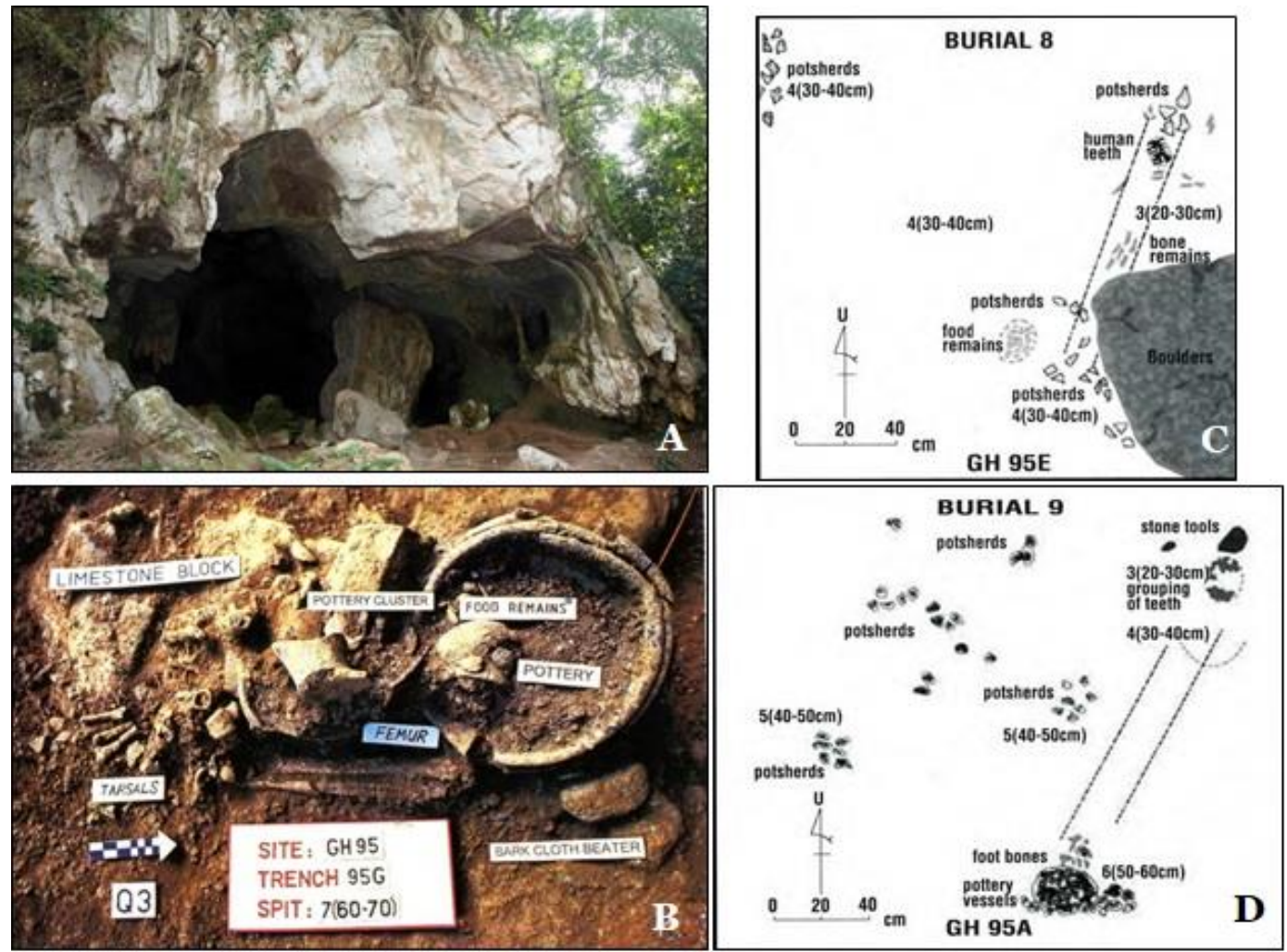

Figure 18. (A) Gua Harimau site, (B) Stacked shallow bowls containing food remains (upper right) found in a burial in Gua Harimau, (C) Burial 8 revealed a cluster of human teeth and bones associated with pottery and food remains, (D)Burial 9 and it associated finds (Source: Department of National Heritage 2011)

The cave floor is hard and covered with chunks of stalactites and the interior portion of the cave had been badly distributed by guano diggers. Gua Harimau was briefly 
A Geotouristic Itinerary of Geosites: A Proposal for Geotourism

and Archaeotourism Development of Lenggong Valley, Perak, Malaysia

investigated by Williams-Hunt in 1951 who found skeletal remains of a juvenile associated with a stone adze and pottery that was radiocarbon dated to $3,450 \pm 150$ BP (WilliamsHunt, 1952). Further excavations conducted by the USM during the 1987-88 seasons uncovered seven more human burials (burial 1-7), dated between 4,900 and 700 years ago (Zuraina, 1988; Zolkurnian, 1989). A total of 13 skeletons including one discovered by Williams-Hunt in 1952 and another recently have been excavated from Gua Harimau while there is no evidence of this cave having been used as a habitation site.

In 1995, four more human burials (Burial 8-11), dated between 3,000 and 3,200 years ago were also found (Zolkurnian, 1998). These burials, uncovered over the years 1987-1995 and labelled from 1 to 11 were found incomplete and in very fragile conditions. A variety of burial items such as earthenware vessels, stone tools, stone adze, bark-cloth beater, shells and stone ornaments, food remains, bronze celts and bronze moulds were associated with this burial Zuraina, 1988; Zolkurnian, 1989; Chia and Zolkurnian, 2005). According to the recent find it seems likely that this cave was used mainly as a cemetery from the late Neolithic to the early Metal periods (Department of National Heritage, 2011). Gua Harimau also hold the most representative set of pottery found among the cave sites. Most were cord marked bowls and footed vessels shaped from local clay which were common throughout prehistoric mainland Southeast Asia. The Gua Harimau pottery assemblage comprising footed vessels, craniate bowls and a single globular vessel defines the pottery culture for the Lenggong Valley. These potteries are well-developed and appear to be of late Neolithic design radiocarbon date about 3,000 years ago and have been formed with local clay. The pottery was sand-tempered; hand moulded using the slow wheel and fired at 600-800 degrees Celsius. Similar pottery assemblages have been found in southern Thailand. Analysis of the human remains indicates that they were a Mongoloid group similar to others found in Asia dating from the Neolithic period. The bronze finds are the earliest in the Malay Peninsula, and so far this is the only archaeological site containing evidence of occupation in the Lenggong Valley during the metal period (Department of National Heritage, 2011). Related activity can be done here is limited to visiting for research and educational purposes only.

\section{Gua Badak $\mathbf{C}$}

Gua Badak C is a small cave located in other massive limestone, approximately $13 \mathrm{~km}$ north of the Lenggong town. It is situated at latitude $5^{\circ} 09^{\prime} 7$ " $\mathrm{N}$ and longitude $100^{\circ} 59$ ' 101 " E and is about 126 meter above sea level. There are several small caves in this massive limestone and were given the same name (Gua Badak). The cave is elongated north-south and extends about $50 \mathrm{~m}$ with two distinct narrow northeast southwest branches. Its entrance is located $12 \mathrm{~m}$ above ground level (Figure 19A). It can be reached via four wheel drives, walking and climbing for 10 minutes. Gua Badak $\mathrm{C}$ has preserved a mass of vertebrate fossil in the cave deposits. Ros and Yeap (2000) first documented some of the fossilized teeth and bones of mammals in Gua Badak C. The fossils contain a highly diversify fauna ranging from large carnivores and herbivores to small fossils (Figure 19B, C) like bats (Yasamin et al., 2010). They related the preservation of the large vertebrate fossil bones and teeth to the time when the Tampanian community was thriving on the plains of Lenggong and Kota Tampan. The common opinion is that the preservation of these fossil bones and teeth in the Gua Badak $\mathrm{C}$ took place more than 30,000 years ago and probably prior to the blockage to the Sungai Perak basin by several landslides. Aboriginal charcoal drawings were also found in a small cave at Gua Badak (Badak A) that located about 250300 m northeast of Gua Badak C where vertebrate fossils were found. Evans (1927) - in Adi (1990) noted charcoal drawings in Gua Badak A (Figure 19D). The oldest of these aboriginal paintings found is only about 120 years at Lenggong (Price, 2001). They were 
then thought have been destroyed and lost by quarrying. Related activity can be done here is limited to visiting for research and educational purposes only.
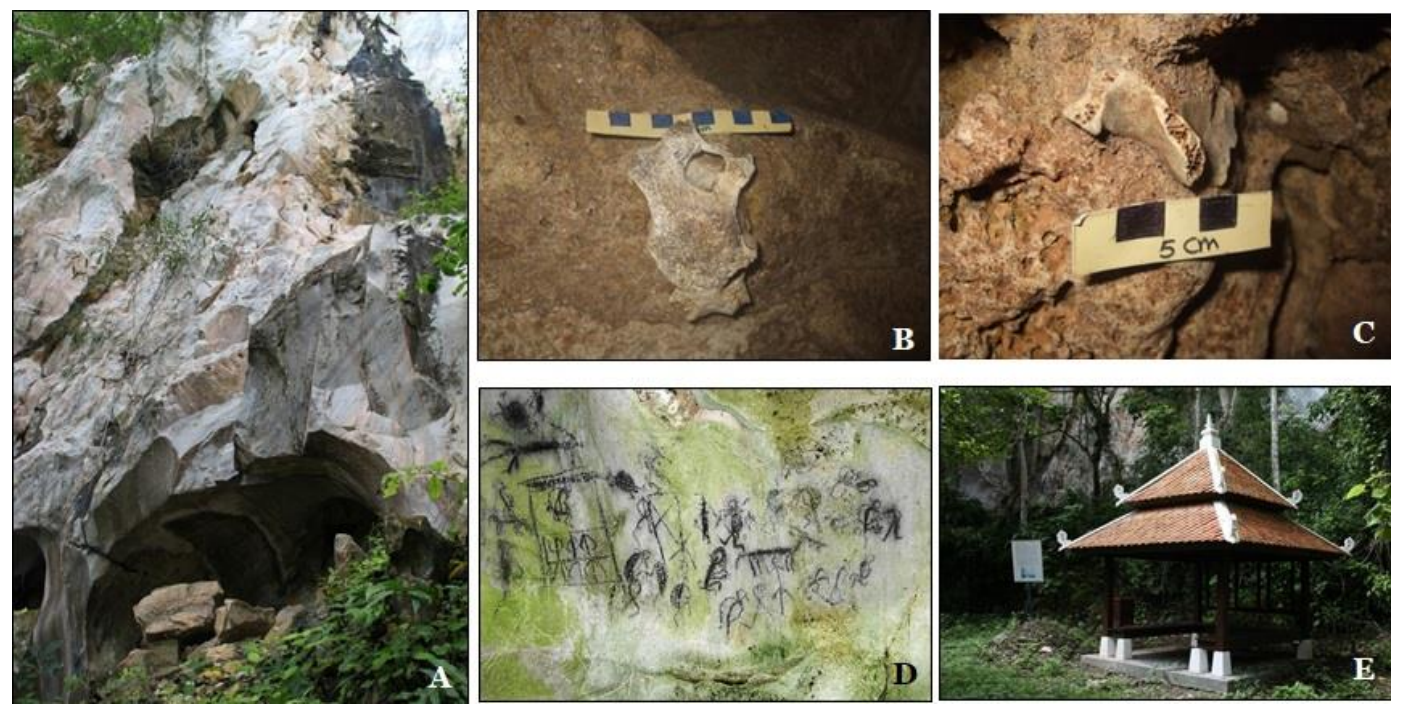

Figure 19. (A) Gua Badak $C$ site, (B, C) Unidentified large mammalian bone fossils in Gua Badak C, (D) Charcoal painting in Gua Badak A by local aborigines bring the Lenggong Valley sequence up to historical times, (E) The site was equipped with gazebo and information board (Source: Yasamin et al. 2010 A, B, C)

\section{DISCUSSION AND CONCLUSION}

AHLV is an excellent example of the recognition of an area with a strong geological and archaeological interest. The proposed geological itinerary is mainly developed and designed to present to an audience of non-experts and experts, the geological phenomenon and a journey through the longest hominid histories in a single locality in the world (Palaeolithic-Neolithic-Metal period). The itinerary described in this paper explained about twelve sites of geological and archaeological interest distributed within Lenggong Valley. Scientific interest, accessibility and clear outcrops associated with geological, historical and cultural resources were essential components for the development of this geological itinerary. The proposed itinerary has been established due to a desire to present the uniqueness and possible fragilities of the described geosites. The proposal of this itinerary is also aimed at creating an opportunity to raise awareness of the geological and archaeological features present in the AHLV which need to be protected and promoted. Bukit Bunuh meteorite impact crater, open air sites, limestone massifs and their caves, river gravel, Toba ash deposit, Sungai Perak and waterfalls provide fundamental information on the important of local and regional cultural and natural features of this area.

They form part of the natural features of the landscape and they represent a valuable scientific and educational resource as well as a great tourism potential. Accordingly, the present study required to identify all those sites for which it is possible to define a "geological-cultural interest" and to provide a basis to preserve and safeguard them for future generations. The proposed itinerary from Lenggong Valley may be used for different purposes, targeting a diverse public ranging from non-specialists to academic geologists. It is particularly suitable as a geotouristic trail and for educational field trips at an undergraduate level for two reasons: its location as a protected area (World Heritage Site) and the remarkable scientific and cultural values of this area. The development of the 
geological itinerary shows how geological and archaeological knowledge that is established on scientific research can be widely disseminated. The proposed itinerary has been established based not only on the presence of sites of great scientific interest but also on the beauty of the landscape of the whole area. The chosen geosites allow us to tell the story through deep time and will provide tourists with the opportunity to increase their scientific knowledge of the Earth directly in the field. The simplified version of Lenggong Valley geotourism map and itinerary are shown in Figure 20 and Table 2. Consequently, the two-full day is needed to cover all the geosites in Lenggong Valley.

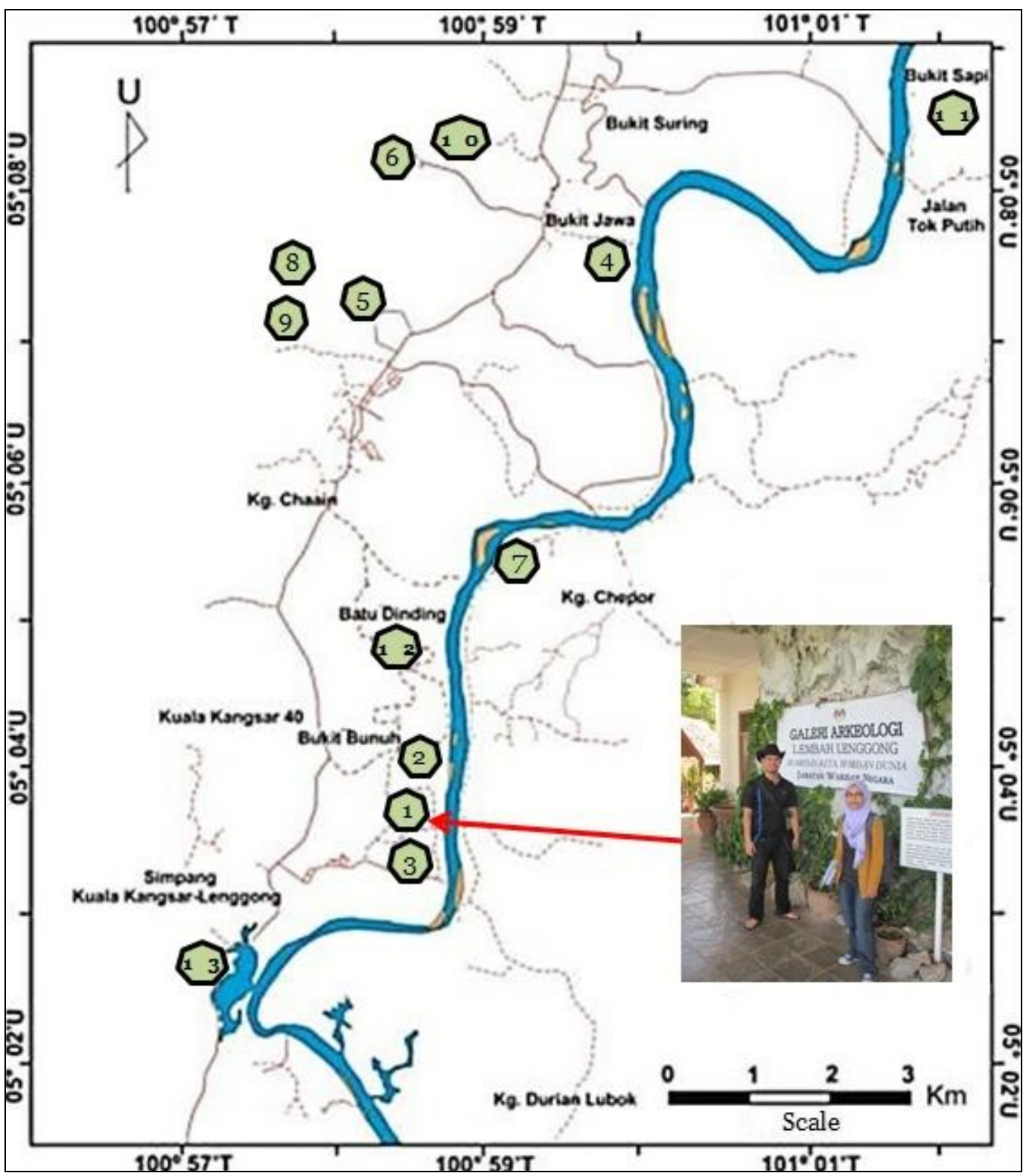

Figure 2o. The simplified version of Lenggong Valley geotourism map 
Mat Stafa RAPIDAH, Kamal Roslan MOHAMED, Che Aziz ALI, Mohd Shafeea LEMAN, Mokhtar SAIDIN

Table 2: Tour Itinerary of Geosites in Lenggong Valley (refer to Figure 20)

\begin{tabular}{|l|}
\hline \multicolumn{1}{|c|}{ Lenggong Valley Geotourism Map and Itinerary } \\
\hline \multicolumn{1}{|c|}{ Day } \\
1. Visit Lenggong Archaeological gallery to get overview of the AHLV before visits and get \\
entrance pass for site visits. \\
2. Visit Bukit Bunuh and appreciate geological site and meteorite impacts. \\
3. Visit and learn about Palaeolithic tools workshop at Kota Tampan \\
4. Enjoy excavation activities at Bukit Jawa and learn about Palaeolithic tools workhsop. \\
5.Visit Lenggong Archaeology Research Centre at Gua Kajang to learn and observe \\
archaeological evidences and activities as well as Gua Asar and Gua Puteri. \\
6. Visit Gua Harimau to observe archaeological artifacts. \\
7.Enjoy water activities at Sungai Perak.
\end{tabular}

\section{Day 2:}

8. Visit Gua Gunung Runtuh and learn about iconic discovery of Perak Man.

9. Visit Gua Teluk Kelawar to observe archaeological artifacts.

10. Visit Gua Badak to observe aboriginal charcoal drawing.

11. Visit Bukit Sapi to observe exposed outcrop of fresh Toba ash deposition.

12. Visit Batu Berdinding to observe several geological structures such as recumbent folds, overturned folds, asymmetrical folds, shear zones, fault zones and clear poles.

13. Enjoy leisure activities such as swimming and fishing at Lata Kekabu.

As a conclusion, the AVLH is a truly unique locality on Earth when considering the geological and archaeological perspectives that are interacting with one another. The above-described geosites can be used to develop an itinerary suitable for different educational groups such as students of high school level, schoolteachers, geotourists and geopark guides and for university courses. The higher educational program should include a course for first year university students as well as courses of study for advanced undergraduate and graduate students who are specializing in geology and archaeology.

Until now, geoconservation procedures have only partially been established in the Lenggong Valley area. Therefore, it is also believed that the development of the geological itinerary could strongly contribute to promote further geoconservation actions. A more disseminated knowledge of this itinerary will encourage planning authorities to pay more attention and to prepare actions for geoconservation and the development of geotourism (Hose, 2008) and, hence, in a short time, geoconservation procedures for all the described geosites will be set up. It is important to focus on conserving geological heritage because it interrelates scientific and cultural significance and thus encourages sustainable development for touristic opportunities especially in geo-archaeotourism potential within this area.

\section{Acknowledgments}

The authors would like to thank Associate Prof. Dr. Kadderi Md Desa for his previous collaboration and supervision. The authors acknowledge anonymous reviewer for their thoughtful suggestion and comments. The authors would also like to thank Centre for Global Archaeological Research (PPAG), USM (APEX Delivery Excellent DE 2012 grant) for giving us this fund to run this research project. We also would like to appreciate the local authority (National Heritage Department (JWN), Lenggong District Council (MDL), Town and Country Planning Department (JPBD), Department of Survey and Mapping Malaysia (JUPEM) and Lenggong Archaeological Museum and local community for their great cooperation during conducting this research. 
A Geotouristic Itinerary of Geosites: A Proposal for Geotourism

and Archaeotourism Development of Lenggong Valley, Perak, Malaysia

\section{REFERENCES}

Adi, H. T. (1990). Conservation and Management Problems of Rock Art Sites in Peninsular Malaysia. Persatuan Sejarah Malaysia.

Bentivenga, M., Palladino, G., Prosser, G., Guglielmi, P., Geremia, F., \& Laviano, A. (2017). A Geological Itinerary Through the Southern Apennine Thrust Belt (Basilicata-Southern Italy). Geoheritage, 9 (1), pp. 1-17.

Bulbeck, D., \& Zuraina, M. (2007). Gua Teluk Kelawar 1 and Holocene Human Evolution in Peninsular Malaysia. In. Saidin, M., Chia, S., (eds.), Archaeological Heritage of Malaysia. Centre for Archaeological Research Malaysia, Universiti Sains Malaysia. (1), pp. 17-39.

Chia, S., \& Zolkurnian, H. (2005). Gua Harimau, A Prehistoric Cemetery in Lenggong, Perak. In Zuraina Majid (ed.), The Perak Man and Other Prehistoric Skeletons of Malaysia Penang: Universiti Sains Malaysia Press, pp. 363-383.

Duckworth, W. L. (1934). Human Remains from Rock-shelters and Caves in Perak, Pahang and Perlis and from Selinsing. Journal of the Malayan Branch of the Royal Asiatic Society, 12, pp. 149-167.

Evans, I. H. N. (1918). Preliminary Report on Cave Exploration, Near Lenggong, Upper Perak. Journal of the Federated Malay States Museums, 7, pp. 227-234.

Evans, I. H. N. (1927). Negrito Cave Drawings at Lenggong, Upper Perak. Journal of the Federated Malay States Museums, 12 (4), pp. 105-106.

Fassoulas, C., Mouriki, D., Dimitriou-Nikolakis, P., \& Iliopoulos, G. (2012). Quantitative Assessment of Geotopes as an Effective Tool for Geoheritage Management. Geoheritage, 4 (3), pp. 177-193.

Foo, K. Y. (1990), Geology and Mineral Resources of the Taiping-Kuala Kangsar Area, Perak Darul Ridzuan. Geological Society of Malaysia Bulletin.

Gatti, E., Saidin M., Nur Khairunnisa, T., Nur Asikin, R., Philip, G., \& Clive, O. (2013). Depositional Processes of Reworked Tephra from the Late Pleistocene Youngest Toba Tuff Deposits in the Lenggong Valley, Malaysia. Quaternary Research, 79, pp. 1-14.

Goh, H. M. (2008). Bukti Kebudayaan Pleistosen Akhir hingga Holosen Awal di Gua Kajang, Lenggong, Perak. Master Thesis, Universiti Sains Malaysia. Unpublished.

Hose, T. A. (2008). Towards A History of Geotourism: Definitions, Antecedents and the Future. In. Burek, C. V., Prosser, C. D., (eds.) The History of Geoconservation. London: Geological Society, pp. 37-60.

Komoo, I. (2004). Geoheritage Conservtion and Its Potential for Geopark Development in Asia-Oceania. In: Leman. M. S., Komoo, I., (eds), Geological Heritage of Malaysia - Theoritical Framework and Assessment of Geoheritage, LESTARI UKM, Bangi, pp. 221-230.

Kubalíková, L. (2013). Geomorphosite Assessment for Geotourism Purposes. Czech Journal of Tourism, 2 (2), pp. 80-104.

Migon, P., \& Pijet-Migon, E. (2016). Interpreting Geoheritage at New Zealand's Geothermal Tourist SitesSystematic Explanation Versus Storytelling. Geoheritage, 9 (1), pp. 83-95.

Mohamed, K. R., Nur khairunnisa, T., Saidin, M., Jeffrey, A., Nur Asikin, R., \& Ali, C. A. (2012). General Geology and Stratigraphy of Bukit Bunuh Area and Its Vicinity. In. Hamzah, M., Saidin, M., (eds.) International Conference on Archaeology of Meteorite Impact at Bukit Bunuh Area, Lenggong, Perak, Malaysia 2012: Extended-Abstract of the International Conference on Archaeology of Meteorite Impact at Bukit Bunuh Area, Lenggong, Perak, Malaysia, Penang, Malaysia, 15-18 July 2012, Centre for Global Archeaological Research, Penang, pp. 9-10.

Muhammad Farhan M. T. (2013). Petrologi Batuan dan Potensi Geopelancongan Kawasan Lata Kekabu, Lenggong, Perak. B.Sc. Thesis, Universiti Kebangsaan Malaysia. Unpublished.

Newsome, D., \& Dowling, R. K. (2010). Geotourism. The Tourism of Geology and Landscape. Goodfellow, Oxford.

Nur Asikin, R. (2013), Pemilihan Jenis Batuan oleh Masyarakat Prasejarah di Kawasan Impak Meteorit Bukit Bunuh, Lenggong, Perak dan Sumbangannya kepada Teknologi Paleolitik. M.Soc.Sc Thesis, Universiti Sains Malaysia. Unpublished.

Nur Khairunnisa, T., Jeffrey, A., \& Saidin, M. (2007). Evidence of Meteorite Impact in Bukit Bunuh and its Contribution to Archaeology. Proceeding of International Seminar on Sharing Our Archaeological Heritage, Yayasan Warisan Johor.

Ólafsdóttir, R., \& Dowling, R. (2014). Geotourism and Geoparks - A Tool for Geoconservation and Rural Development in Vulnerable Environments : A Case Study from Iceland. Geoheritage, 6 (1), pp. 71-87.

Palladino, G., Prosser, G., \& Bentivenga, M. (2013). The Geological Itinerary of Sasso di Castalda: A Journey into the Geological History of the Southern Apennine Thrust-belt (Basilicata, Southern Italy). Geoheritage, 5 (1), pp. 47-58.

Panizza, M., \& Piacente, S (2008). Geomorphology and Cultural Heritage in Coastal Environments. Geografia Fisica e Dinamica Quaternaria, 31 (2), pp. 205-210.

Price, L. (2001). Caves and Karst of Peninsular Malaysia. Gua Publication. Kuala Lumpur, Malaysia.

Reynard, E. (2008). Scientific Research and Tourist Promotion of Geomorphological Heritage. Geografia Fisica e Dinamica Quaternaria, 31, pp. 225-230. 
Ros F. M., \& Yeap, E. B. (2000). Proposed Conservation of Badak Cave C, Lenggong as Vertebrate Fossil Site Extraordinary. Proceeding of Annual Geological Conference 2000. Geological Society of Malaysia, pp. 189-196.

Rushdan, A. L. (1994). Geologi Am Kawasan Lenggong-Lawin, Perak. B.Sc. Thesis Universiti Malaya. Unpublished.

Saidin, M. (1993), Kajian Perbandingan Tapak Paleolitik Kampung Temelong dengan Kota Tampan dan Sumbangannya Terhadap Kebudayaan Zaman Pleistosen Akhir di Asia Tenggara. Malaysian Museums Journal, 32.

Saidin, M. (2004). Pleistocene Lithic Technology and Adaptation in Souteast Asia: New Evidence from Malaysia. Kertas Kerja Seminar 75th Aniversary of the Discovery of the First Skull of the Peking Man and 10oth Birthday of Late Prof. W.C. Pei, Beijing, 17-24 Oktober 2004.

Saidin, M. (2007a). Paleolithic Adaptation: Some Criteria for Habitation Site Selection Among the Pleistocene Population in Malaysia. Archaeological Heritage of Malaysia, 1.

Saidin, M. (2007b). Kehidupan Manusia Prasejarah di Hulu Perak: Sumbangannya kepada Warisan Geologi Negara. In: Leman, M. S., Ali, C. A., Komoo, I., (eds), Geological Heritage of Malaysia (Conservation of Geoheritage and Protection of Environment), LESTARI UKM, Bangi, pp. 201-210.

Saidin, M., \& Jeffrey, A. (2007). Sungai Perak Kuno: Sumbangannya kepada Zaman Paleolitik Malaysia. Jurnal Arkeologi Malaysia, 20, pp. 14-21.

Saidin, M. (2012a). Historic Discovery of Meteorite Impact at Bukit Bunuh, Lenggong Perak. In. Hamzah, M., Saidin, M., (eds.) International Conference on Archaeology of Meteorite Impact at Bukit Bunuh Area, Lenggong, Perak, Malaysia 2012: In. Hamzah, M., Saidin, M., (eds.) International Conference on Archaeology of Meteorite Impact at Bukit Bunuh Area, Lenggong, Perak, Malaysia 2012: ExtendedAbstract of the International Conference on Archaeology of Meteorite Impact at Bukit Bunuh Area, Lenggong, Perak, Malaysia, Penang, Malaysia, 15-18 July 2012, Centre for Global Archeaological Research, Penang, pp. 1-2.

Saidin, M. (2012b). Absolute Date of Bukit Bunuh Impactites. In. Hamzah, M., Saidin, M., (eds.) International Conference on Archaeology of Meteorite Impact at Bukit Bunuh Area, Lenggong, Perak, Malaysia 2012: In. Hamzah, M., Saidin, M., (eds.) International Conference on Archaeology of Meteorite Impact at Bukit Bunuh Area, Lenggong, Perak, Malaysia 2012: Extended-Abstract of the International Conference on Archaeology of Meteorite Impact at Bukit Bunuh Area, Lenggong, Perak, Malaysia, Penang, Malaysia, 15-18 July 2012, Centre for Global Archeaological Research, Penang, pp. 15-17.

Scrivenor, J. B. (1931). The Geology of Malaya. London: MacMillan Press.

Stauffer, P. H., Batchelor, B. (1978). Quaternary Volcanic Ash and Associated Sediments at Serdang, Selangor. Warta Geologi, 4, pp. 7-11.

Stauffer, P. H. (1973). Late Pleistocene Age Indicated for Volcanic Ash in West Malaysia. Geological Society of Malaysia Newsletter, 40, pp. 1-4.

Tjia, H. D. (1993). Kota Tampan: A Late Pleistocene Palaeolithic Workshop on the Shore of Palaeo-Chenderoh Lake in Perak. Warta Geologi, 19 (2), pp. 29-34.

Williams-Hunt, P.D.R. (1952). Archaeological Discoveries in Malaya. Journal of the Malayan Branch of the Royal Asiatic Society, 25, pp. 181-190.

Yasamin, K. I., Lee, C. P., Ros, F. M., Earl, C., Lim, T. T., \& Kira, E. W. (2010). Vertebrate Fossils from Badak C Cave, Lenggong, Perak in Peninsular Malaysia. Abstract of Warta Geologi, 36, (2).

Zolkurnain H. (1998). Urutan Kebudayaan Prasejarah Lembah Lenggong, Hulu Perak Pada Zaman Holosen. Master Thesis. Universiti Sains Malaysia. Unpublished.

Zolkurnian H. (1989). Gua Harimau: Satu Laporan Awal. Jurnal Persatuan Muzium Malaysia, 8, pp. 41-52.

Zuraina, M. (1988). Indigenous Malaysian Bronze Manufacture or Not? Short Notes of New Evidence from Gua Harimau in Perak, North Malaysia. Paper presented at the International Conference of Ancient Bronze Drums and Bronze Cultures in Southern China and Southeast Asia. Kunming, China.

Zuraina, M. (1994). The Excavation of Gua Gunung Runtuh and the Discovery of The Perak Man in Malaysia. Kuala Lumpur: Department of Museums and Antiquity.

Zuraina, M. (1996). Prasejarah Malaysia: Sudahkah Zaman Gelap Menjadi Cerah?. Pulau Pinang: Universiti Sains Malaysia.

Zuraina, M., Johan, A., Samsuddin, A. R., Nizam, A., Lim, A., Saidin, M., Jeffrey, A., \& Chia, S. (2005). GTK 1: Skeleton from Gua Teluk Kelawar, Lenggong dated 8,400 \pm 40 BP. In: Zuraina Majid (ed), The Perak Man and other Prehistoric Skeleton in Malaysia, Penerbit Universiti Sains Malaysia, Penang.

*** Department of National Heritage, (2011). Archaeological Heritage of the Lenggong Valley: Nomination Dossier for Inscription on the UNESCO World Heritage List.

Submitted:

04.05 .2018
Revised:

11.09.2018
Accepted and published online 14.09.2018 